\title{
FOLLOWERS IN THE ORGANIZATIONAL LEADERSHIP PROCESS: FROM ATTRIBUTION TO SHARED LEADERSHIP
}

\author{
Vesna Stojanovic Aleksic* \\ Faculty of Economics, University of Kragujevac, Kragujevac, The Republic of Serbia
}

\begin{abstract}
Despite the fact that most of the theories and models of leadership are solely focused on the leader as the central figure of the leadership process, there is a need to draw attention to the importance of the followers' role in the organizational leadership process, which is the main subject of this paper. Newer approaches to leadership provide a framework for the study of a reciprocal influence in the leadership process, in which the behavior of the leader appears as both an independent and a dependent variable at the same time. The aim is to draw attention to the necessity of adjusting leadership styles to the characteristics of the followers and encourage the followers' active role in leadership, as the basic precondition for the effectiveness of the entire leadership process. The paper reviews the evolution of the role of the followers in organizational leadership through various approaches and models of leadership, from the attribution of potential leadership qualities through the process of attribution, through the followers' influence in the selection of the dominant leadership style, to the equal participation in the leadership process, reflected in the concepts of servant leadership and shared leadership.
\end{abstract}

Keywords: organization, leadership, followers, leadership process, organizational behavior

JEL Classification: L26, D23, O31, M13

\section{INTRODUCTION}

Although leadership, as a multi-dimensional process, is formed under the influence of a number of factors and is heavily determined by the characteristics of a situation, a large number of researchers still believe that the entire leadership process is largely caused

\footnotetext{
* Correspondence to: V. Stojanovic Aleksic, Faculty of Economics, University of Kragujevac, Dj. Pucara 3, 34000 Kragujevac, The Republic of Serbia; e- mail: vesnasa@kg.ac.rs
}

by the characteristics of the leader, as the key figure and the essential bearer of the whole process. The first theories of leadership put the leader in their focus, with the concept of leadership based on the idea that the leader is born with specific traits, qualities and abilities that enable him/her to establish him-/herself as a leader, and that there are certain predeterminations for the expression of leadership skills (Stoner \& Freeman, 2012). Based on this understanding, the so-called great man theories have been developed, which dominated the early phases of leadership 
research, advocating the notion that people are born as leaders and that great leaders are just born with the predispositions promoting them to outstanding political and organizational leaders (Yukl, 1998). Under the influence of these approaches, the research into the human qualities that form the basis for the formation of a leadership potential, i.e. the development of leaders within companies and other organizations, has been established, which has led to the formulation of that theories explaining the phenomenon of leadership only through a set of personality traits of its bearers, or leaders, where the role of the follower in the leadership process is not considered at all (Northouse, 2008). The fact is that the notions of this approach are still present and, in any study on leadership, it is difficult to bypass the personal characteristics of a leader, while at the same time, the majority of the classical and modern styles of leadership are ultimately just a reflection of one's personal characteristics. It is more than clear, however, that leadership cannot be viewed and interpreted solely through the prism of the physical, mental and social traits of the leader, but also from the viewpoint of the characteristics of the other constituents of the leadership process, more precisely its followers.

Leadership is the ability to influence the followers, in order to achieve organizational goals, by using appropriate motivational techniques based on power and formal or informal authority (Isam, Rehman \& Ahmed, 2013, 81). In this process, the followers have a very important role, because the way how the influence the leader has is perceived by the followers, reciprocally, determines the behavior of the followers in the leadership process. The process of leadership, therefore, includes a set of activities that involves both leaders and their followers, who work together to achieve organizational goals, and also involves multilayered relations, which can only be achieved through the active participation of all relevant members of the leadership process. This implies that the process of leadership involves a two-way mutual influence of the leader on his/her followers, and the one the followers have on their leader, which is why it can be argued that the leadership process is an inseparable unity of its most important segments and thereby the function of the three essential variables: the leader, the followers and the situation (Yukl 1998; Northouse, 2008; Daft, 2011). It is clear that this is a social process that can never be one-way, and therefore should not be viewed solely from the perspective of the leader, but also from the perspective of the other constituents. The behavior of a leader, leadership styles and interpersonal relations have a multiple effect on the followers, or vice versa, which is why it is essential to explore different aspects of the phenomenon of leadership from the perspective of the follower, which is the main subject of the research conducted in this paper.

The examining of the role of the followers in the process of leadership is important for several reasons. First, due to the fact that all people, sooner or later, find themselves in a position to be someone's follower (Kelley, 1989). This refers even to leaders with an extremely strong position of authority, given to the nature of situational leadership, i.e. the fact that a leader in one situation can become a follower in another, and vice versa. What is, however, of particular importance is what relates to the fact that the followers are immanent to the leadership process itself, which, by definition, implies a reciprocal relationship and mutual exchange of impacts on the leader-follower relation.

The aim of the paper is to highlight the importance of the role of the followers in the leadership process, and the fact that the quality of the leadership process, in addition to the characteristics of the leader, is significantly conditioned by the characteristics of the followers, who are not just passive participants in this process, but have an active role (and sometimes the key role) in its creation and functioning. Having this in mind, the aim is to draw attention to the necessity of adjusting the leadership styles to the characteristics of the followers and encouraging the active role of the followers, as the basic precondition for the effectiveness of the entire leadership process.

In accordance with the given subject and aim of the research, a scientific hypothesis is designed - the quality of the leadership process, in addition to leaders' characteristics, is conditioned by the characteristics of the followers, and there is an interdependence between the effectiveness of the leadership process and the active role of the followers in the process. 
The qualitative methodology was applied, based on the descriptive study, comparison and interpretation of the relevant scientific achievements within the defined problem area, for the synthesis of different positions, based on which the general conclusions about the role of the follower in the leadership process were derived. The theoretical verification was achieved by applying the method of analysis, synthesis, deduction and induction, with the aim to achieve adequate general conclusions through abstraction and generalization.

Having in mind the identified subject, the aim and the scientific hypothesis, the paper is, after the introductory remarks, divided into four parts. In the first part, the importance of attribution is pointed out, as one of the essential role of the followers in shaping the leadership process. Then, in the second part of the paper, the early approaches to the analysis of the leadership process are considered, inclusive of the perspective of the follower, such as the models of leadership styles conditioned by the degree of the followers' maturity, then the theories oriented towards the leader's role in the process of motivating the followers while they are achieving organizational goals. In the third part of the paper, the concept of the leader-member exchange is presented, based on the idea of individualized leadership, i.e. the establishing of the individual relationships between the leader and the follower. The fourth section analyzes the approaches to leadership focused on the followers as the primary holders of the leadership process, embodied in the concepts of servant leadership and shared leadership.

\section{THE ROLE OF ATTRIBUTION IN THE LEADERSHIP PROCESS}

In the context of the study of the followers' most important roles in the process of leadership, the dynamics of the leadership process have been specifically perceived through attribution theory (Yukl, 1998; Bowditch, Buono \& Stewart, 2008; Northouse, 2008). This theory suggests that the leadership process, for the most part, is based on the perception of the followers, whereas the perception of the leadership qualities, abilities and styles depends on the cognitive capacities of the followers to perceive certain characteristics of the people suitable to fit into the scheme of the mental qualities a leader should possesses. If the followers have implicit assumptions about how a leader should look and behave in a certain situation, they are prone to attribute leadership skills to anyone who adopts certain aspects of such a behavior, regardless of whether they possess such skills or not. In other words, if the behavior of a particular individual has led to positive effects and results, each time the effects are repeated, the follower will attribute the abilities of a leader to that person, regardless of whether the result is actually the result of his/her leadership skills or not.

Each leadership process is based on the strong interaction between the leader and the people following him/her, whereas the essential segment of such an interaction is reflected in the processes of one's personal identification and internalization (Shamir, House \& Arthur, 1993; Yukl, 1998). One's personal identification with the leader is one of the key elements in leadership development, present with all followers, and it is a particularly characteristic of the followers who have problems regarding their personal identity, low self-esteem and a high need for dependence on authority. Equally important is the process of social identification, which includes people's tendency to define themselves primarily through their membership in a particular group or organization, seeing it as an important part of their social identity (Shamir, House \& Arthur, 1993; Yukl, 1998). When social identification is extremely high, people are willing to subordinate their individual needs to the group, sacrificing their own personal interests in favor of the group and the leader, attributing to the leader those traits that are perceived as desirable, no matter if the leader possesses them or not. Effective leaders are able to increase the level of social identification in different ways (for example, by giving the group specific features, symbols, rituals, making it so different from other groups), while increasing their influence on the followers of the group.

The second segment of the leader's impact on the followers through the process of attribution is reflected in internalization. In this process, the followers' value system is associated with the group's values, i.e. organizational values, so that the followers are 
encouraged to freely express their own values and expectations, which are then incorporated into the mission, vision and goals of the organization (Shamir, House \& Arthur, 1993). Thus, internal motivation is encouraged and people are motivated to focus on internal incentives, such as self-expression and selfpromotion, but in such a manner as it is not contrary to the interests of the organization itself. Attribution at the stage of internalization is reflected in attributing the leader's values compatible with the followers' value system of, after which the leader is perceived as someone similar to the followers and therefore worthy of being engaged and of the investment of the follower's energy in him/her. This variant attribution is known as "egocentric attribution" and refers to the natural tendency of every individual to better evaluate people like themselves assessed by any standard (sometimes even by the attributes related to the physical appearance).

The processes of the identification and internalization of leadership are eased by the need on the followers' part to identify themselves with the leader whose qualities are the subject of their own idealization and admiration, this being so to the extent when approval and acceptance by the leader becomes the most important measure of the followers' value. Many followers see the leader's acceptance as the primary source of motivation, on the one hand, whereas, on the other, they are also driven by a fear of disapproval and rejection.

Apart from the relation between the leader and the follower, attribution in the leadership process also takes place through an interaction among the followers themselves. This process, which is called "social contamination" (Meindl, 1990), explains the development of leadership in cases where there is no direct interaction between leaders and their followers, so the direct influence of the leader could not appear. Social contamination involves the spontaneous spread of emotions and reactions in a particular group, which happens after loosening inhibitions due to the fact that the group member has observed the same or similar behavior in the other members of the group. It is believed, namely, that the real social identity of people is inhibited by social norms and the standards of acceptable behavior and that people often do not behave in accordance with their true nature, but rather in accordance with the rules of the group which they want to fit in (Meindl, 1990). If there is a leader whose behavior deviates from the accepted norms, he or she is likely to be accepted by those members who share the lowest level of identification with the group. Because they find it hard to identify themselves with the group, these members will tend to identify themselves with the leader, imitating a non-specific behavior, verbal and non-verbal messages, symbols, rituals and the like. In contact with these members of the group, other members will, as a result of social contamination, accept such behavior over time, even though it was initially unacceptable for them. The more the inhibition mechanism loosens, the more freely the members of the group will accept the model of the new behavior, even though they are not in direct contact with the leader, which is the result of a mutual interaction and the imitation of the followers (Meindl, 1990). The attributes of leadership will be attributed to the group leader due to the individuals' need to rationalize their feelings and behavior (Conger \& Kohungo, 1990). As people have already accepted the leadership behavior that does not fit in with the usual social norms, they will justify it by attributing the leader with exceptional qualities and skills (if someone has so many qualities, it is acceptable to identify with him/her). This reflects the essence of attribution in the leadership process: the attribution of leadership traits to the member of the group whose behavior is perceived as leading, regardless of his or her real traits (Conger \& Kohungo, 1990). In modern circumstances, taking into consideration the use of the mass media, social networks and the Internet, the process of social contamination occurs much faster than before, and attribution is more often realized without the immediate presence of leaders.

There are patterns of the leader's behavior that are more favorable for the attribution process. Thus, for example, more capacity is attributed to the leaders whose vision is in a significant discrepancy with the existing state of affairs, as well as to those who use unconventional methods of the implementation of a vision (the more unusual the strategy for achieving goals, the more capacity is attributed to the leader). This is also applied to the leaders prone to taking an 
extremely high risk, especially if such a risk is related to their personal status and position, as well as to those characterized by an exceptionally high level of self-confidence, enthusiasm and energy (Meindl, 1990).

\section{AN EARLY OVERVIEW OF THE FOLLOWERS' ROLE IN THE LEADERSHIP PROCESS}

The general attempts of the theories of personality to define the personality traits, behaviors and principles of leadership that would be universally valid for most situations, putting the leader in the center of the leadership process, have been responded to by the emergence of certain theories emphasizing the flexible leadership approach and the necessity for establishing correspondence between the leader's behavior and style and the requirements of specific situations. These theories and models have been developed as a result of the belief that an understanding of leadership process must include the conceptualization of different situational variables, of which the most important ones to consider are the followers' characteristics.

One of the first models, which shifted the focus of the study of the leadership process from the leader to the followers, is the situational leadership model, founded by P. Hersey and K. Blanchard (1989), who advocate the idea that the relationship between the two basic dimensions of the leader's behavior (an orientation towards tasks and the orientation towards humans) is formed depending on the characteristics of the followers. The Hersey-Blanchard model of leadership is based on the establishment of the relations between the leadership styles of guidance and a social support for the group members, on the one hand, as well as readiness, i.e. the maturity of the followers that they exhibit in carrying out specific tasks, on the other. This situational variable represented a new dimension of the leadership processes in comparison to the previous ones, and their prominence in the foreground emphasizes the role of the followers as an important factor of any leadership process. In this way, the spotlight has shifted from the leader to the followers, whose role is considered as essential, both because they are the ones who can accept or reject the leader and the fact that their characteristics determine the leadership style that will be applied in a concrete situation.

In contrast to the perceptions of maturity in absolute terms, the notion of maturity in the situational theory of leadership, in organizational terms, is interpreted as "the ability and willingness of people to direct their behavior towards achieving a specific task" (Hersey \& Blanchard, 1989). Maturity, therefore, in this case, is seen as a relative category in relation to the specific task and circumstances, which implies that an individual or a group may be willing and able to perform one piece of work, but not to perform another one. The concept of maturity in the Hersey-Blanchard model consists of the two key components (Hersey \& Blanchard, 1989):

- business maturity (ability) is reflected in knowledge, experience and training to carry out a specific task without direct guidance and supervision;

- psychological maturity (readiness) involves motivation and the will to take action, including commitment, confidence and willingness to take responsibility.

The combination of these components defines the level of the maturity that is expressed through the levels, whereby different levels of maturity in the matrix ",task orientation/interaction orientation", imply the use of different styles of leadership (Hersey \& Blanchard, 1989). The essence of this leadership model is reflected in the fact that the level of the followers' maturity determines the optimal type of the leader's behavior, in the sense that, the increasing of the followers' maturity and readiness makes the leader's orientation towards interaction and support grow, while a decline in their maturity leads to the implementation of the directive leadership styles.

The path-goal theory that significantly promoted the follower's role in the leadership process is oriented towards the followers' motivation in the leaderfollower relationship in order to increase satisfaction; consequently, the greater engagement of the followers in the process of the realization of organizational goals is expected (House, 1971). The leader's motivational 
function in this process is to increase a reward for the achieved results and create a path that facilitates the obtaining of rewards by explaining, removing barriers and increasing opportunities for achieving satisfaction for the realization of a task. The basis of the pathgoal theory is the understanding that the leaders will be effective to the extent that they complement the environment in which their followers work through the necessary clarifications of the given tasks, ensuring that the followers can achieve organizational goals, feel personal satisfaction and receive adequate rewards for the achieved goals (House, 1996; Kamisah \& Wafa, 2014). The leaders will successfully motivate their followers if they make business results desirable and if they help their followers to understand the behaviors and the strategies that make a link between the achievement of the desired results and the rewards (House \& Mitchell, 2000; Knight, Shteynberg \& Hanges, 2004). The followers' perception of the prize largely depends on the leadership style - if leaders provide assistance and support, giving a clear course of action and the path for achieving a goal, then even the behavior of a leader can be seen as a specific reward.

The theory is based on two general assumptions. First, a leadership behavior is acceptable and satisfactory to the followers only if it is perceived as a source of current or as an instrument for achieving future satisfaction. Second, the behavior of a leader will act as motivating to the extent it brings the followers' needs into function with effective performance, while the leader has to contribute to creating an environment that will stimulate higher performance, providing support and help. In this regard, R. J. House (1996) thought that the leader's basic functions can be fulfilled by applying one of the four styles of leadership behavior:

- Directive style - the leader emphasizes the formal activity, provides a clear directive, plans, policies, procedures and standards.

- Supporting style - the leader pays attention to the members of the group and creates a climate of emotional support, acts friendly and treats subordinates as equals.
- Participatory style - the leader consults with the followers and considers their ideas when making decisions.

- Achievements-oriented style - the leader encourages employees to take complicated tasks, sets challenging goals, rewards them for exceptional results and promotes employees' selfesteem.

Which leadership style would dominate in certain circumstances depends on a number of contingent variables, which are within the path-goal model classified into the following two groups:

- the personal characteristics of the followers, such as the locus of control, the ability to perform a task, the need for achievement, experience and the need for task to be clearly defined;

- the characteristics of the environment, such as the degree of the task structure, the system of formal authority and the characteristics of the working group.

The above-mentioned features are the situational moderators that determine the potential for increasing the followers' motivation and the leadership style that will suit specific conditions. The evaluation of situational factors can help predict the effects of the impact of certain leadership styles on the employees' attitudes and performance and consequently the choice of an adequate style in particular circumstances. So, for example, when a task is stressful, dangerous or, in turn, boring and disincentive, supporting the style can contribute to increasing confidence, reducing anxiety and minimizing the unpleasant aspects of the job, which will lead to the followers' increased job satisfaction and effort. If a task is unstructured and complex and the followers inexperienced, if there is the weak formalization of the rules and procedures, the most appropriate style would be a directive one, since it will generate greater satisfaction and a greater effort. Directive behavior reduces uncertainties present when roles and tasks are not clearly defined; it is necessary to delineate responsibility in order to establish the rules and guidelines to ensure precise operation. The behavior style oriented towards achievements is adequate in cases when tasks are not repetitive, thus 
representing a special challenge for employees; so, leaders need to increase the followers' confidence and encourage the expectation that they will achieve the set of goals successfully and competently, whereas the participatory style is suitable in situations when it is necessary to include the followers in decision-making, as well as in cases when the followers have a strong need for autonomy and independence.

The most important implications of the theory of the followers' maturity and the path-goal theory refer to the confirmation of the position that leaders may possess and use more than one of the leadership styles and that the choice of a leadership style is directly determined by the followers' characteristics and their needs.

\section{AN INDIVIDUALIZED APPROACH TOWARDS LEADERSHIP: LEADER- MEMBER EXCHANGE THEORY}

The early theories of leadership studies perceived leadership as an activity undertaken by the leader towards all of his/her followers, the members of the same group, uniformly, using the so-called average leadership style (Northouse, 2008). Recent studies question this assumption, pointing to the fact that the leader establishes a specific relationship with each follower individually and that this relationship is realized through an exchange carried out through developed interpersonal relationships, which means that usually the leader does not behave in the same way with all his/her followers, but establishes highlevel relations with some followers and lower-quality relations with others.

Unlike the previous theories and approaches to leadership, which view this process through the leader's establishment of relations with the whole group, the two-way approach focuses on the relation between the leader and an individual member of the group, indicating that leadership is not a process uniformly manifested to all members of the organization, but the leader rather forms a specific relationship with each member of the group individually, which implies that there is no behavior generally oriented towards tasks or interpersonal relationships, but rather that each leader-member interaction must be considered separately (Graen \& Uhl-Bien, 1995; Yukl, 1998; Green, 2008; Daft, 2011).

The two-way approach to leadership, in the literature known as the Vertical Dyad Linkage - VDL model, is based on the leader-member individual exchange, and therefore called the Leader Member Exchange - LMX. The basic premise of this approach is based on the idea of the reciprocal influence of leaders on followers, which can take two different forms. Most leaders are believed to have established specific exchange relations with a small number of members of a group, with whom they have close relations and who are given the role of their assistants and advisers, whereas the rest of the group members become relatively neglected, or they may establish somewhat worse relations with the leader, which is why they are often seen as opponents to the leader (Northouse, 2008). In the exchange with these members of the group, a relatively low level of mutual influence is exerted, which is based mainly on the legitimate sources of power and authority and implemented within the framework defined by formal rules and procedures. The complex exchange relations established with the preferred members of the group mean more attention to, more recognition of and more opportunities for advancement for those members, in return for which, greater involvement, commitment to the objectives and the mission and greater loyalty to the leader are expected.

Members of the inner group, among whom a closer exchange relation is established, are selected on the basis of the followers' skills, their motivation to take responsibility and the extent to which leaders believe that their followers can be trusted. The followers who show a higher degree of efficiency and have similar personality traits as their leader will become members of internal groups sooner because of the effect of the socalled egocentric attribution (Schyns, Kroon \& Moors, 2008). These followers contribute to the execution of a task more than they are expected to according to the formal requirements of the job and take responsibility for the performance of the activities that are the most critical ones to the success of the organization. They are specially treated by the leaders, in the sense that they provide a greater amount of information, greater 
commitment, attention, support in career development and understanding, and enjoy greater trust and care from the leader (Jiang, Law \& Sun 2014). The followers of the inner group have more opportunities to speak openly, exchange information and ideas with their supervisor and use more communication channels in comparison to the followers from an outer group (SueChan, Chen \& Lam, 2011). These followers are more satisfied, achieve better performance, show greater creativity and innovation and are more committed to the organization than the followers from an outer group (Van Breukelen, Schyns \& Le Blanc, 2006; Lee, 2008; Moss, Sanchez, Brumbaugh \& Borkowski 2009; O’Donnell, Yukl \& Taber, 2012; Abu Elanain, 2014). The followers of the inner group rarely leave their jobs and are given more appraisals for their performance. Leaders and the followers with whom they have close relationships help each other in their careers and personal life, often through their collaborating at work as well as informally, outside their work. Highquality exchange relationships between a leader and the members of the inner group can be considered as a kind of social capital, which has a positive impact on overall organizational performance (Moss et al, 2009; Jiang et al, 2014).

Members of the outside group are mainly engaged in routine tasks (Stewart \& Johnson, 2009) and have a formal relationship with their superiors, which is characterized by low confidence, a lack of attention, support and fewer opportunities for prizes (Moss et al, 2009). Followers of the outside group only perform the tasks they are engaged in and act in compliance with the formal description of their work (Abu Elanin, 2014), have fewer contacts with the leader, fewer resources and limited access to information. The leader provides them with support and help, but only to the extent of his duty and professional obligation. These followers have fewer chances for advancement, are often feel isolated and neglected and it is more difficult for them to develop the sense of attachment and commitment to the organization, experiencing their position as an extremely unfair one (Loi, Mao \& Ngo, 2009).

Recent research in this area focused on efforts to develop an exchange model that would allow the establishment of effective relations among the leaders and all the members of the group, despite the fact that these relations are still based on individualized relationships. The emphasis is on the effort to provide all employees with an opportunity to participate in the quality process of the leader-member exchange, thereby generating benefits for all participants in this process: the leaders, the followers and the organization as a whole (Daft, 2011). In this context, the leader examines each follower separately and treats him or her as an individual, developing in this way a special form of the so-called "individualized leadership", which implies an active development of positive relations with all the members of the group, although this relationship takes on a different form for each individual (Daft, 2011). This means that the leader in his or her efforts can manifest different behaviors simultaneously, but some individuals will receive more of his care and concern, in accordance with the orientation towards interaction, while the others will experience his or her more directive behavior, in accordance with the orientation towards the task, all this depending on the individual characteristics of the followers.

The systemic perspective of this theory suggests a possibility of the expansion of vertical two-way connections to other paths, which implies the establishment of the leader-member exchange outside the traditional boundaries of the functions and divisions, even beyond the organizational framework. This implies efforts to expand leadership relations in order to include all relevant stakeholders, enabling the leader to selectively use his or her abilities, thus creating positive relationships with as many people as possible and expanding his or her field of influence.

\section{THE SERVANT AND SHARED LEADERSHIP CONCEPTS}

Servant leadership is a perspective of the leadership process entirely directed to the followers, in which the leader's role is not seen as being directive in any segment, but only as being supportive, and the leader's main tendency is not to dominate, but rather help the followers (Greenleaf, 1998). According to this concept, the leader's position does not provide privileges, but rather obliges, and must be earned by providing 
support and assistance to the followers. „The only authority that should be accepted is the one which is obtained in exchange for assistance. The only leaders to follow are the ones who have proven themselves as helpers, ready to serve first, and only after to lead" (Greenleaf, 1998, 25).

Unlike traditional leadership that weights the effectiveness of the leadership process against custom classical outputs, servant leadership observes efficiency in the context of realizing the needs of the members of the organization, such as satisfaction, advancement, self-fulfillment, autonomy, security etc. Traditional leaders prefer instructions and directives, whereas servant leaders place an emphasis on assistance, facilitation and guidance, which will allow their followers to fully perceive their environment and understand the demands placed before them. The two fundamental premises determine the nature of servant leadership: the leader's desire to serve others, the need to serve something with a higher goal or purpose and something going beyond the scope of their own interests, on the one hand, and the leader's willingness to share their power with their followers (Greenleaf, 1998).

Servant leaders try to create a sense of community within and loyalty to the organization, motivating their followers to engage themselves beyond the scope of their current job roles, encouraging their personal and professional development and continuous learning (Kreitner \& Kinicki, 2012). They are characterized by the ability to actively listen, understand the needs and wishes of their staff, express empathy and trust in the good intentions of their followers, even when outcomes are poor. In the context of the aforementioned approach of the leader-member exchange, servant leadership implies the highest degree of the individualization of leadership, in which all followers occupy the position of internal members of the group in relation to the highquality exchange. It requires the complete adaptation of the leadership style to the specific needs, capabilities and limitations of each follower individually, assigning leadership roles to the followers whenever it is possible (Kreitner \& Kinicki, 2012). In this manner, the clear distinction between the leader and his/her followers is lost, although in the case of servant leadership a group has no problem to identify the leader, even though he/ she is outside the formal position of authority.

An essential prerequisite for strengthening the role of the followers in the leadership process in an organization is based on the separation of power, since power is the key dimension of leadership necessary for influencing (Keley, 1988). The traditional leadership approach promotes the idea that power is of a fixed quantity, and that if one person has more power, another has necessarily less. Naturally, people understanding it in that way are not willing to share power, believing that if someone has less power, it is easier to manipulate them. Practice, however, has showed that a lack of power in the subordinate ones leads to the drastic weakening of motivation and poor results, and similar is true for leaders - those whose power is based only on their legitimate position, lacking other forms of power, tend to apply the autocratic style of leadership, and the creation of a system in which political abilities dominate the leadership ones and the protection of their own interests become the priority, which is why the followers become discouraged, frustrated and uncooperative (Gardner, Avolio, Luthans, May \& Walumbwa, 2005).

Numerous studies have shown that if the followers believe they are more influential, powerful and in control of certain segments of the business, the greater their personal satisfaction is, which has a positive impact on the overall efficiency of the organization (Greenleaf, 1998; Daft, 2011; Jiang et al, 2014). Between the distribution of power and a success, there is usually a high degree of correlation - those parts of the organization where there is a greater division of power between the leaders and their followers show greater efficiency and a higher degree of power in all (Bucic, Robinson \& Ramburuth, 2010). For these organizational subsystems, it is characteristic that their leaders do not see power as an indivisible good, but rather realize that the success of the whole group is higher if more of the group members have developed a sense of power and ability to influence. The concept of sharing power implies certain reciprocity of influence, which means that both the leader and the follower are ready to mutually influence each other (Pierce \& Newstorm, 2015). Working to strengthen the other, the leader puts him-/herself on an equal footing with the 
followers, motivating them so that they support his/ her ideas, instead of sabotaging them. This leads to reverse synergy effects, so the leader generates more power than he or she previously had.

One of the key assumptions of independence and shared leadership is allowing followers to make decisions without their being constantly checked by the leader, which gives them a sense of personal autonomy and self-control and causes an increase in power and motivation (Pierce \& Newstorm, 2015). In this regard, it is necessary for a leader to be consistent in his or her intentions to promote the inclusion of a follower in solving problems from the earliest stages, to be genuinely committed to the task and serve his or her followers as an example. It is essential, therefore, that the followers should have confidence in their leader, and the leader must, on his or her part, believe in the capability and capacity of his or her followers, too, supporting them and ensuring the possibility of obtaining information, education and the development of new knowledge and skills. The followers of these leaders feel a strong affiliation to the group and commitment to the work they do, they are responsible for their own obligations and ready for continuous training (Newstorm \& Pierce, 2014). Shared leadership involves a continuous process of identifying the leadership potential among employees and encouraging them to develop these resources in order to occasionally find themselves in the role of a leader (Stojanović Aleksic, Domanović, 2012; Eric Nielsen, 2015).

The implementation of the concept of shared leadership implies certain characteristics of the followers, whose role has changed from a passive to an active one, for which reason they can be described as effective followers. Effective followers are characterized by a sense of personal responsibility for achieving the defined goals and sharing the organizational mission. They take an initiative for activities ensuring the improvement of their own potential while trying to recognize and meet the needs of the organization along with the leader (Kelly, 2012). In addition, they are characterized by the ability to clearly and freely express their views and stand up to the leader if, in doing so, they can prevent actions that could undermine the integrity or the goals of the organization (Kelly, 2012; Pierce \& Newstorm, 2015).

The followers' effectiveness is conditioned, therefore, by the ability to integrate the two opposing follower's roles - the one related to the implementation of decisions made by the leader and the other concerning the need to review the leader's decisions and activities and to propose creative solutions. This is particularly important in the process of dealing with the transformational changes in the organization, when a follower's readiness to deal with uncertainty and risk has become a critical factor for the success of his or her initiation and guidance.

Transformational changes require the implementation of transformational leadership, the concept of which is very close to the concept of shared leadership and different from transactional leadership, if compared with the latter. Transactional leadership is based on the principle of exchange (transactions) between the leader and the follower, whereby the follower invests his or her resources and engages in achieving a particular goal in exchange for various types of awards received from the leader (Tichy \& Devanna, 1996). This relationship, which is very reminiscent of the classical superior-subordinate relationship, can be successful in the implementation of the current objectives of the organization, but very rarely leads to substantial organizational changes (Georgiades \& Macdonell, 2008). On the other hand, transformational leadership involves inspiration and energy to mobilize the followers to change the existing situation in the organization, simultaneously transforming the followers themselves in order to strengthen their effective role in the leadership process.

Transformational leadership is based on the three essential components: the vision, energy and empowerment (Tichy \& Devanna, 1996). It therefore necessarily involves creating a compelling vision of what we want to realize in the process of change, the development of strategies and modeling behavior that is going to lead to its realization. In addition, transformational leadership requires a significant commitment of energy, both from the leader and the follower, for which reason they are required a greater effort and commitment, alongside demonstrating 
their own initiatives and faith in a mutual success, as well as promoting and rewarding any significant shift in the desired direction. The third component of transformational leadership is related to the empowerment of the followers and includes personal support and assistance, the demonstration of understanding, willingness to share their feelings with the members of the organization as well as the demonstration of confidence in their ability to adequately respond to the challenges of change, which are also the qualities of the shared leadership concept. In a sense, transformational leadership can be said to require transformational followers.

\section{CONCLUSION}

The leadership process is conditioned by various factors, including the leader's characteristics, the power structure, the requirements of the specific situation, the follower's characteristics, as well as feedback on the impact of various styles of the leader's behavior on the follower's performance (Pierce \& Newstorm, 2015). Thus, it is necessary that leadership should be considered as an interactive process determined by a multitude of variables; therefore, an entire complex of relevant factors must be integrated into the leadership model, with a special emphasis on the followers' characteristics. An important feature of any leadership process is that it is always conducted within the context of certain groups and within the context of the specific situation; so, having that in mind, the various aspects for identifying the impact leaders have on their followers, and vice versa, should be regarded.

Contemporary organizational circumstances emphasize the need for leaders to be at the service of their followers, open to all sorts of ideas and suggestions, ready to support, assist and encourage more efforts and commitment, which is why one of the most important criteria for a successful leader is the extent to which his or her followers are successful, happy and able to lead themselves. Effective leaders realize that there are limits to what you can do yourself and that one of the ways for you to overcome them is to keep your followers capable and motivated, using your own power at the service of the development of the other members of the organization. Even the leaders of the autocratic type would not be able to successfully operate unless at least one of their followers were given a sense of power, inspiring them in that way to complete the given objectives (Kouzes \& Posner, 2007).

The context of the continuous organizational changes characteristic of the modern environment requires the full and active commitment of all the actors of the leadership process, which implies the necessity of leaving the negative conception of the role of the followers, referring to them as passive and dependent participants of the leadership process, and replacing it with a positive one, inclusive of the followers who are responsible, proactive and willing to change, ready to take risk and continuously learn (Chaleff, 2005).

The formation of effective leader-member relations requires an objective assessment of the position of the leader, which excludes the idealization of his or her personality and role, which is not easy to achieve because the majority of the leaders are idealized by their followers to a lesser or greater extent (Ansari, Hung Mui \& Aafaq, 2007). On the other hand, it is necessary for the followers to estimate themselves realistically, registering their strengths and limitations, analyzing everything that is important for the achievement of mutual trust and support in relation to the leader. Creativity, initiative, a tendency to change, willingness to take responsibility and contribute to the development of the organization are all desirable traits of the followers, who make up an important part of the leadership process, and are necessary for the realization of the concept of shared leadership. In modern organizational circumstances, the important feature of the effective follower is related to his or her willingness and ability to abandon the leadermember relations, if the follower is not satisfied with his or her own status in the leadership process, or if he or she is not able to meet the demands imposed by the leader. This means that no leadership process should be regarded as a permanent structure, but only as a temporary balance of power, always connected with specific situational circumstances, implying the rotational nature of the leader's and the follower's roles. 
The scientific contribution of the paper, in the theoretical sense, is reflected in emphasizing the importance of the research in the leadership phenomenon from the follower's perspective, as well as in highlighting the follower's role in the process of organizational leadership as active and equal participants in this process. In this context, the scientifically valid hypothesis that the quality of the leadership process, apart from being conditioned by the leader's characteristics, is also conditioned by the follower's characteristics and that there is interdependence between the effectiveness of the leadership process and the active role of the followers in that process is confirmed. The theoretical approach synthesized in the paper is the basis for conducting a possible future theoretical and empirical research study, and its practical contribution is reflected in providing organizational leaders with the guidelines on how to involve the followers in the decision making process and the division of power more actively, as well as how to adapt the leadership style to the followers and the requirements of situational circumstances.

The biggest limitation is a lack of empirical research that would investigate into the follower's characteristics in the context of the cultural and organizational specifics of domestic enterprises, and examine concrete relations in respect of the leader-member exchange in the process of organizational leadership in our country. Future research will focus on the elimination of these shortcomings, especially in analyzing the impact of national and organizational culture on the establishment of leader-follower relations, as well as the consideration of the cultural restrictions on the use of servant leadership and shared leadership.

It is evident that the leadership process in modern organizations cannot be carried out independently from the active participation of the followers; so, in the years to come, the follower's role will increasingly be gaining in importance, both in theory and in organizational practice. Accordingly, a greater number of empirical research studies in the context of this problem area may be expected, which will be one of the directions for the future research to be conducted by the author of this paper.

\section{REFERENCES}

Abu Elanain, H. M. (2014). Leader-member exchange and intent to turnover: Testing a mediated-effects model in a high turnover work environment. Management Research Review, 37(2), 110-129. 10.1108/MRR-09-2012-0197

Ansari,M.A.,MuiHung,D.K.,\&Afaqi,R.(2007).Leader-member exchange and attitudinal outcomes: role of procedural justice climate. Leadership \& Organization Development Journal, 28(8), 690-709. doi:10.1108/01437730710835443

Bucic, T., Robinson, L., \& Ramburuth, P. (2010). Effects of leadership style on team learning. Journal of Workplace Learning, 22(4), 228-248. doi: 10.1108/13665621011040680

Bowditch, J. L., Buono, A. F., \& Stewart, M. M. (2008). A Primer on Organizational Behavior. $7^{\text {th }}$ edition. New York, NY: Wiley.

Chaleff, I. (2005). The Courageous Fellower: Standing up to and for our Leaders. San Francisco, USA: Berrett Koehler Publishers.

Conger, J., \& Kohungo, R. (1990). A behavioral attribute measure of charismatic leadership in organizations. Academy of Management Meetings, 637-647.

Daft, R. L. (2011). Leadership: Theory and Practice. Forth North, USA: The Dryden Press.

Eric Nielsen, J. (2015). Corporate entrepreneurship, organizational learning and knowledge implementation. Economic Horizons, 17(3), 2013-217. doi: 10.5937/ ekonhor1503203E

Gardner, W. L., Avolio, B. J., Luthans, F., May, D. r., \&Walumbwa, F. (2005). Can you see the real me? A self-based model of authentic leader and follower development. The Leadership Quarterly, 16(3), 343-372. doi:10.1016/j.leaqa.2005.03.003

Georgiades, N., \& Macdonell, R. (2008). Leadership for Competitive Advantage. Chichester, UK: John Wiley\&Sons.

Graen, G. B., \& Uhl-Bien, M. (1995). Relationship-based approach to leadership: Development of leader-member exchange $(\operatorname{lmx})$ theory of leadership over 25 years: Applying a multi-level multi-domain perspective. Leadership Quarterly, 6(2), 219-247. doi:10106/1048-9843(95)90036-5

Green, C. (2008). Leader member exchange and the use of moderating conflict management styles: Impact on relationship quality. International Journal of Conflict Management, 19(2), 92-111. doi:10.1108/1044406810856058

Greenleaf, R. (1998). Servant Leadership. In L. C. Spears (Ed.), Insights on Leadership. New York, NY: John Wiley\&Sons.

Hersey, P., \& Blanchard, K. H. (1989). Management of Organizational Behavior: Utilizing Human Resources. New 
York, NY: Prentice Hall.

House, R. J. (1971). A path goal theory of leader effectiveness. Administrative Science Quarterly, 16(3), 321-339. doi:10.2307/2391905

House, R. J. (1996). Path-goal theory of leadership: Lessons legacy and a reformulated theory. The Leadership Quarterly, 7(3), 323-352. doi:10.1016/S1048-9843(96)90024-7

House, R. J., \& Mitchell, T. R. (2000). Path-Goal Theory of Leadership. New York, NY: McGraw Hill.

Isam, T., Rehman, S., \& Ahmed, I. (2013). Investigating the mediating role of organizational politics between leadership style and followers' behavioral outcomes. Business Strategy Series, 14(2/3), 80-96. doi.10.1108/17515631311325123

Jiang, J. Y., Law, K. S., \& Sun J. J. M. (2014). Leader-member relationship and burnout: The moderating role of leader integrity. Management and Organization Review, 10(2), 223-247. doi: 10.1111/more.12022

Kamisah, D. A. B., \& Wafa, S. A. (2014). The leadership style preference among sabah ethnicities. International Journal of Human Resource Studies, 4(1), 259-265. doi:10,5296/ ijhrsv4i1.5708

Kelley, R., (1988). In price of followers. Harvard Business Review, Novembar, 142-158. Retrieved May 20, 2016, from https://hbr. org/1988/11/in-praise-of-followers

Kelly, R. (2012). The Power of Followership. New York, NY: Doubleday.

Knight, A. P., Shteynberg, G., \& Hanges, P. J. (2004). Path-goal analysis. In J. M. Burns, G. R. Goethals, \& G. J. Sorenson (Eds.), Encyclopedia of leadership (pp.1164-1169). Massachusetts, USA: Sage Publications.

Kouzes, J., \& Posner, B. (2007). Leadership Chalenge. San Francisco, USA: Jossey Bass Publishers.

Kreitner, R., \& Kinicki, A. (2012). Organizational Behavior. New York, NY: MC Graw Hill.

Lee, J. (2008). Effects of leadership and leader-member exchange on innovativeness. Journal of Managerial Psychology, 23(6), 670-687. doi:10.1108/02683940810894747

Loi, R., Mao, Y., \& Ngo, H. (2009). Linking leader-member exchange and employee work outcomes: The mediating role of organizational social and economic exchange. Management and Organization Review, 5(3), 401-422. doi: 10.1111/j.1740-8784.2009.00149.x

Meindl, J. R.(1990). On Leadership: An Alternative to Conventional Wisdom. In B. M. Staw, \& L. L. Cummings
(Eds.), Research in Organizational Behavior (pp. 159-189). Vol. 12.

Moss, S. E., Sanchez, J. I., Brumbaugh, A. M., \& Borkowski, N. (2009). The mediating role of feedback avoidance behavior in the LMX - performance relationship. Group \& Organization Management, 34(6), 645-664. doi: 10.1177/1059601109350986

Northouse, P. G. (2008). Leadership: Theory and Practice. Massachusetts, USA: Sage Publications Inc.

O'Donnell, M., Yukl, G., \& Taber, T. (2012). Leader behavior and LMX: a constructive replication. Journal of Managerial Psychology, 27(2), 143-154. doi: 10.1108/02683941211199545

Pierce, J., \& Newstrom, J. (2014). Leaders and the Leadership Process. New York, NY: IRWIN.

Pierce, J., \& Newstorm, J. (2015). The Managers Bookshelf. New Yersey, NY: Prentice-Hall.

Schyns, B., Kroon, B., \& Moors, G. (2008). Follower characteristics and the perception of leader member exchange. Journal of Managerial Psychology, 23(7), 772-788. doi: 10.1108/02683940810896330

Shamir, B., House, R. J., \& Arthur, M. B. (1993). The motivational effects of charismatic leadership: A self-concept based theory. Organization Science, 4(4), 577-594. doi: 10.1287/orsc.4.4.577

Stewart, M. M., \& Johnson, O. E. (2009). Leader - member exchange as a moderator of the relationship between work group diversity and team performance. Group \& Organization Management, 34(5), 507-535. doi: 10.1177/105960110833122

Stojanović Aleksić, V. i Domanović, V. (2012). Uticaj promena poslovnog ambijenta na stilove liderstva. U V. Leković (Ur.), Institucionalne promene kao determinanta privrednog razvoja Srbije (str. 295-308). Kragujevac, Republika Srbija: Ekonomski fakultet Univerziteta u Kragujevcu.

Stoner, F., \& Freman, R. (2012). Management. New York, NY: Prentice-Hall.

Sue-Chan, C., Chen, Z., \& Lam, W. (2011). LMX, coaching attributions, and employeeperformance.Group\&Organization Management, 36(4), 466-498. doi: 10.1177/1059601111408896

Tichy, N. M., \& Devanna, M. A. (1996). The Transformational Leadership. New York, NY: Wiley.

van Breukelen, W., Schyns, B., \& Le Blanc, P. (2006). Leadermember exchange theory and research: Accomplishments and future challenges. Leadership, 2(3). 295-316. doi: 10.1177/1742715006066023

Yukl, G. (1998). Leadership in Organizations. 8th Edition, New York, NY: Pearson Education. 


\section{Received on $5^{\text {th }}$ June 2016, after revision, accepted for publication on $22^{\text {nd }}$ August 2016. \\ Published online on $26^{\text {th }}$ August 2016.}

Vesna Stojanovic Aleksic is an Associate Professor at the Faculty of Economics, the University of Kragujevac, where she obtained her PhD in Management and Business Economics. She teaches the following subjects: Organization of Enterprise, Organizational Behavior and Leadership and Organizational change. The main areas of her scientific interests are related to organization, organizational change, leadership and organizational behavior. 


\title{
SLEDBENICI U PROCESU ORGANIZACIONOG LIDERSTVA: OD ATRIBUCIJE DO PODELJENOG VOĐSTVA
}

\author{
Vesna Stojanović Aleksić* \\ Ekonomski fakultet Univerziteta u Kragujevcu
}

\begin{abstract}
Bez obzira na činjenicu da je najveći broj teorija i modela liderstva fokusiran isključivo na lidera kao centralnu figuru liderskog proesa, postoji potreba da se skrene pažnja na značaj i ulogu sledbenika u procesu organizacionog liderstva, što je osnovni predmet istraživanja ovog rada. Noviji pristupi liderstvu daju okvir za proučavanje recipročnih uticaja u liderskom procesu, u kojima se ponašanje lidera pojavljuje i kao nezavisna i kao zavisna promenljiva u isto vreme. Cilj rada je da se ukaže na nužnost prilagođavanja liderskih stilova karakteristikama sledbenika, i podsticanja aktivne uloge sledbenika u liderstvu, kao osnovnog preduslova efektivnosti kompletnog liderskog procesa. U radu je razmatrana evolucija uloge sledbenika u organizacionom liderstvu, kroz različite pristupe i modele vođstva, od pripisivanja potencijalnih liderskih osobina kroz proces atribucije, preko uticaja karakteristika sledbenika na odabir dominantnog liderskog stila, do ravnopravnog učeśća u liderskom procesu, reflektovanog u konceptima uslužnog liderstva i podeljenog vođstva.
\end{abstract}

Ključne reči: organizacija, liderstvo, sledbenici, liderski process, organizaciono ponašanje

JEL Classification: L26, D23, O31, M13

\section{UVOD}

Iako se vođstvo, kao višedimenzionalni proces, formira pod uticajem velikog broja faktora i determinisano je karakteristikama situacije, kod određenog broja istraživača ostaje uverenje da je kompletan liderski proces, $u$ najvećoj meri, uslovljen osobinama samog lidera, kao ključne figure i njegovog suštinskog nosioca. Prve teorije liderstva su u fokusu liderskog

\footnotetext{
* Korespondencija: V. Stojanović Aleksić, Ekonomski fakultet Univerziteta u Kragujevcu, Đ. Pucara 3, 34000 Kragujevac, Republika Srbija; e-mail: vesnasa@kg.ac.rs
}

procesa imale isključivo lidera, pri čemu se poimanje liderstva zasnivalo na shvatanju da se lideri rađaju sa specifičnim osobinama, kvalitetima i sposobnostima koje im omogućavaju da se nametnu kao vođe, odnosno, da $\mathrm{u}$ ispoljavanju liderskih veština postoji izvesna predodređenost (Stoner \& Freman, 2012). $\mathrm{Na}$ temelju ovih shvatanja razvijene su tzv. teorije velikog čoveka (great man theories), koje su dominirale u početnim fazama istraživanja liderstva, a koje su zagovarale stanovište da se ljudi rađaju kao vođe, i da su veliki lideri rođeni sa predispozicijama koje su ih promovisale $\mathrm{u}$ izuzetne političke i organizacione vođe 
(Yukl, 1998). Pod okriljem ovih pristupa, razvijena su istraživanja ljudskih osobina koje predstavljaju bazu za formiranje liderskog potencijala, odnosno razvoj lidera u okviru preduzeća i drugih organizacija, koja su dovela do formulisanja teorija koje fenomen liderstva objašnjavaju isključivo kroz set ličnih osobina njegovih nosilaca, odnosno, lidera, pri čemu uloga sledbenika u liderskom procesu nije razmatrana (Northouse, 2008). Činjenica je da su segmenti ovog pristupa i danas aktuelni i da je, u bilo kojoj studiji o liderstvu, teško zaobići lične karakteristike lidera, kao i da je većina klasičnih i savremenih stilova vođstva, u krajnjoj liniji, refleksija upravo personalnih karakteristika. Međutim, jasno je da se liderstvo ne može posmatrati i tumačiti isključivo kroz prizmu fizičkih, mentalnih i socijalnih odličja lidera, već i iz ugla karakteristika ostalih konstituenata liderskog procesa, odnosno, njegovih sledbenika.

Liderstvo podrazumeva sposobnost uticanja na sledbenike, sa ciljem ostvarenja organizacionih ciljeva, koristeći odgovarajuće motivacione tehnike bazirane na moći i formalnom ili neformalnom autoritetu (Isam, Rehman \& Ahmed, 2013, 81). U ovom procesu sledbenici imaju važnu ulogu, jer način na koji je uticaj lidera percipiran od strane sledbenika određuje, recipročno, ponašanje sledbenika u liderskom procesu. Proces liderstva, dakle, obuhvata set aktivnosti koje uključuju lidera i sledbenike, koji zajednički rade na ostvarivanju organizacionih ciljeva, i podrazumeva višeznačne relacije, koje se mogu ostvariti jedino aktivnim učešćem svih relevantnih subjekata liderskog procesa. Ovo implicira da je proces liderstva dvosmeran, i podrazumeva obostrani uticaj kako lidera na sledbenike, tako i sledbenika na lidere, zbog čega se može tvrditi da je liderski proces nerazdvojiva celina njegovih najznačajnijih segmentata, odnosno, funkcija tri esencijalne promenljive: lidera, sledbenika i situacije (Yukl, 1998; Northouse, 2008; Daft, 2011). Jasno je da se radi o socijalnom procesu, koji nikada ne može biti jednosmeran, pa se zbog toga ne sme posmatrati isključivo iz vizure lidera, već i iz ugla ostalih konstituenata. Ponašanje lidera, liderski stilovi i izgrađene interpersonalne relacije višestruko utiču na sledbenike, ali i obrnuto, zbog čega je neophodno istražiti različite aspekte fenomena liderstva iz ugla sledbenika, što predstavlja osnovni predmet istraživanja ovog rada.

Razmatranje uloge sledbenika $\mathrm{u}$ procesu liderstva značajno je iz više razloga. Najpre, zbog činjenice da se svi ljudi, pre ili kasnije, nađu u prilici da budu nečiji sledbenici (Kelley,1988). Ovo se odnosi čak i na lidere sa pozicijom autoriteta, s obzirom na situacionu prirodu liderstva, odnosno, na činjenicu da lider u jednoj može postati sledbenik u drugoj situaciji, i obrnuto. Ono što je, međutim, posebno značajno, vezano je za to da su sledbenici imanentni samoj prirodi liderskog procesa, koji, po definiciji, podrazumeva recipročnu relaciju i uzajamnu razmenu uticaja u odnosu lider - sledbenik.

Cilj rada je da se ukaže na značaj uloge sledbenika u liderskom procesu, odnosno, na činjenicu da je kvalitet liderskog procesa, pored karakteristika lidera, značajno uslovljen karakteristikama sledbenika, koji nisu samo pasivni učesnici ovog procesa, već imaju aktivnu ulogu (ponekad i ključnu) u njegovom kreiranju i funkcionisanju. Sledstveno ovome, cilj je da se ukaže na nužnost prilagođavanja liderskih stilova karakteristikama sledbenika, i podsticanje aktivne uloge sledbenika, kao osnovnog preduslova efektivnosti kompletnog liderskog procesa.

U skladu sa postavljenjim predmetom i ciljem istraživanja, koncipirana je naučna hipoteza da je kvalitet liderskog procesa, pored karakteristika lidera, uslovljen i karakteristikama sledbenika, odnosno, da postoji međuzavisnost efektivnosti liderskog procesa i aktivne uloge sledbenika u tom procesu.

$\mathrm{U}$ radu je primenjena kvalitativna metodologija, zasnovana na deskriptivnom proučavanju, komparaciji i interpretaciji naučnih dostignuća izdvojenih kao relevantnih $u$ okviru definisanog problemskog područja, radi sintetizovanja različitih stavova, na bazi kojih su izvedeni generalni zaključci o ulozi sledbenika u liderskom procesu. Teorijska verifikacija ostvarena je primenom metoda analize i sinteze, dedukcije i indukcije, sa ciljem da se apstrakcijom i generalizacijom dođe do adekvatnih opštih zaključaka.

Imajući u vidu opredeljeni predmet istraživanja, cilj i naučnu hipotezu, rad je, nakon uvodnih razmatranja, strukturiran $\mathrm{u}$ četiri dela. U prvom delu ukazuje se na značaj atribucije, kao jedne od suštinskih uloga 
sledbenika u oblikovanju liderskog procesa. Zatim se, $u$ drugom delu rada, razmatraju rani pristupi koji $\mathrm{u}$ analizu liderskog procesa uključuju i perspektivu sledbenika, kao što su modeli o uslovljenosti liderskih stilova stepenom zrelosti sledbenika, a zatim i teorije orijentisane na ulogu lidera $\mathrm{u}$ procesu motivisanja sledbenika na putu realizacije organizacionih ciljeva. U trećem delu rada predstavljen je koncept razmene lider-sledbenik, baziran na ideji individualiziranog liderstva, odnosno, uspostavljanja pojedinačnih odnosa lidera sa sledbenicima, dok su u četvrtom delu analizirani pristupi liderstvu koji u fokusu imaju sledbenike kao primarne nosioce liderskog procesa, oličene u konceptima uslužnog liderstva i podeljenog vođstva.

\section{ULOGA ATRIBUCIJE U LIDERSKOM PROCESU}

U kontekstu proučavanja najznačajnijih uloga sledbenika $u$ procesu liderstva, specifičan način viđenja dinamike liderskog procesa dala je atributivna teorija, ili teorija "pripisivanja“ (Yukl, 1998; Bowditch, Buono \& Stewart, 2008; Northouse, 2008). Ova teorija sugeriše da se liderski proces, u najvećoj meri, bazira na percepciji sledbenika, pri čemu percepcija liderskih osobina, sposobnosti i stilova, zavisi od kognitivnih kapaciteta sledbenika da u određenim osobama vide karakteristike koje se uklapaju u mentalnu šemu osobina koje bi jedan lider trebalo da poseduje. Ukoliko sledbenici poseduju implicitne pretpostavke o tome kako u određenoj situaciji lider treba da izgleda i da se ponaša, oni su skloni da svakome ko usvoji određene aspekte takvog ponašanja pripišu liderske sposobnosti, bez obzira na to da li ih osoba realno poseduje ili ne. Drugim rečima, ukoliko je ponašanje određenog pojedinca dovelo do pozitivnih efekata i rezultata, svaki put kad se ti efekti ponove, sledbenik će osobi koja je povezana sa rezultatom pripisati sposobnosti lidera, bez obzira na to da li je rezultat zaista posledica njenih liderskih sposobnosti, ili ne.

Svaki liderski proces zasniva se na snažnoj interakciji lidera i ljudi koji ga slede, pri čemu se suštinski segment interakcija ogleda $\mathrm{u}$ procesima personalne identifikacije i internalizacije (Shamir, House \& Arthur,
1993; Yukl, 1998). Personalna identifikacija sa liderom predstavlja jedan od ključnih elemenata $u$ razvoju liderstva i prisutna je kod svih sledbenika, a posebno je karakteristična za sledbenike sa problemima ličnog identiteta, niskim samopouzdanjem i visokom potrebom za zavisnošću od autoriteta. Pođednako značajan jeste i proces socijalne identifikacije, koja podrazumeva sklonost ljudi da sebe definišu primarno kroz članstvo u određenoj grupi ili organizaciji, doživljavajući ga kao najvažniji deo svog socijalnog identiteta (Shamir, House \& Arthur, 1993; Yukl, 1998). Kada je socijalna identifikacija visoka, ljudi su spremni da svoje individualne potrebe podrede grupnim, žrtvujući lične interese $u$ korist grupe i lidera, pripisujući lideru one osobine koje su od strane sledbnika percipirane kao poželjne, bez obzira na to da li ih lider realno poseduje, ili ne. Efektivni lideri su u stanju da povećaju stepen socijalne identifikacije na različite načine (na primer, dajući grupi specifična obeležja, simbole, rituale, čineći je na taj način različitom od drugih grupa), povećavajući, istovremeno, svoj uticaj na sledbenike u gupi.

Drugi segment uticaja lidera grupe na sledbenike kroz proces atribucije, ogleda se $u$ internalizaciji. $U$ tom procesu se sistem vrednosti sledbenika povezuje sa vrednostima grupe, odnosno, čitave organizacije, tako što se sledbenici podstiču da slobodno izraze sopstvene vrednosti i očekivanja, koje se, zatim, inkorporiraju u misiju, viziju i ciljeve organizacije (Shamir, House \& Arthur, 1993). Na taj način, podstiče se unutrašnja motivacija, i ljudi su ohrabreni da se orijentišu na interne motivacione faktore, kao što su samoizražavanje, napredovanje i samopoštovanje, a da to ne bude $\mathrm{u}$ suprotnosti sa organizacionim interesima. Atribucija u fazi internalizacije ogleda se u pripisivanju lideru vrednosti kompatibilnih sa vrednosnim sistemom sledbenika, nakon čega se lider percipira kao neko sličan sledbenicima, i samim tim, vredan angažovanja i ulaganja sledbeničke energije. Ova varijanta atribucije poznata je pod nazivom "egocentrična atribucija", a odnosi se na prirodnu sklonost svakog pojedinca da bolje vrednuje osobe koje procenjuje sličnim sebi, po bilo kom kriterijumu (ponekad i prema atributima vezanim za fizički izgled). 
Procesi identifikacije i internalizacije $\mathrm{u}$ liderstvu olakšani su potrebom sledbenika da se poistovete sa liderom čije osobine predstavljaju predmet idealizacije i divljenja, $u$ toj meri da odobravanje i prihvatanje od strane vođe postaje najznačajnije merilo vrednosti sledbenika. Mnogi sledbenici prihvatanje od strane lidera vide kao primarni izvor motivacije, s jedne strane, dok su, s druge strane, motivisani strahom od liderovog neodobravanja i odbacivanja.

Osim kroz odnos lidera i sledbenika, atribucija u liderskom procesu odvija se i kroz interakcije između samih sledbenika. Ovaj proces, koji se naziva i „socijalna kontaminacija“ (Meindl, 1990), objašnjava razvoj liderstva u slučajevima kada ne postoji direktna interakcija između lidera i sledbenika, pa se ne može ni pojaviti neposredni uticaj lidera. Tzv. socijalna kontaminacija podrazumeva spontano širenje emocija i reakcija u određenoj grupi, što se dešava nakon popuštanja inhibicija usled toga što je član grupe observirao isto ili slično ponašanje kod drugog člana grupe. Veruje se, naime, da je pravi socijalni identitet ljudi inhibiran socijalnim normama i standardima prihvatljivog ponašanja, $\mathrm{i}$ da se ljudi najčešće ne ponašaju u skladu sa svojom prirodom, već u skladu sa pravilima grupe u koju žele da se uklope (Meindl, 1990). Ukoliko se pojavi lider čije ponašanje odudara od ustaljenih normi, on će najbrže biti prihvaćen od strane onih članova koji dele najniži stepen identifikacije sa grupom. Zbog toga što se teško identifikuju sa grupom, ovi članovi će težiti da se identifikuju sa liderom, oponašajući njegovo nespecifično ponašanje, verbalne i neverbalne poruke, simbole, rituale i slično. U kontaktu sa ovim članovima grupe i ostali članovi će, usled socijalne kontaminacije, vremenom prihvatiti takvo ponašanje, čak i ukoliko im je na početku izgledalo neprihvatljivo. Što više mehanizmi inhibicije budu popuštali, to će članovi grupe slobodnije prihvatati model novog ponašanja, $i$ onda kada se ne nalaze $\mathrm{u}$ neposrednom kontaktu sa liderom, što je rezultat međusobne interakcije i oponašanja sledbenika (Meindl, 1990). Atributi liderstva biće pripisani vođi grupe, zbog potrebe pojedinaca da racionalizuju svoja osećanja i svoje ponašanje (Conger \& Kohungo, 1990). Pošto su ljudi već prihvatili ponašanje lidera koje ne odgovara uobičajenim socijalnim normama, opravdaće to pripisivanjem lideru izuzetnih kvaliteta i sposobnosti (ako neko ima toliko kvaliteta, prihvatljivo je identifikovati se sa njim). U ovome se upravo ogleda suština atribucije u liderskom procesu: pripisivanje liderskih atributa članu grupe čije je ponašanje percipirano kao lidersko, bez obzira na njegove realne osobine (Conger \& Kohungo, 1990). U savremenim uslovima, upotrebom medija masovnog komuniciranja, društvenih mreža i interneta, proces socijalne kontaminacija se odvija neuporedivo brže nego ranije, a atribucija se realizuje sve češće bez neposrednog prisustva lidera.

Postoje obrasci ponašanja lidera koji više pogoduju procesu atribucije. Tako će, na primer, više sposobnosti biti pripisano lideru čija se vizija nalazi u značajnoj diskrapanci u odnosu na postojeće stanje stvari, kao i liderima koji koriste nekonvencionalne metode njenog ostvarivanja (što strategija ostvarenja ciljeva više odstupa od uobičajene, to će se lideru pripisati više ekstra sposobnosti). Ovo, takođe, važi i za lidere koji su skloni preuzimanju ekstremno visokog rizika, naročito ukoliko je to što rizikuju vezano za njihov lični status i poziciju, kao i za one koji ispoljavaju izuzetno visok nivo samopouzdanja, entuzijazama i energije (Meindl, 1990).

\section{RANO SAGLEDAVANJE ULOGE SLEDBENIKA U LIDERSKOM PROCESU}

Kao odgovor na univerzalistička nastojanja teorija ličnosti da definišu osobine, ponašanja i principe liderstva koji bi bili opštevažeći za najveći broj situacija, stavljajući lidera u centar liderskog procesa, pojavljuju se teorije koje akcentiraju fleksibilan pristup vođenju i nužnost uspostavljanja korespondencije između ponašanja i stila lidera i zahteva konkretne situacije. Ove teorije i modeli razvijeni su kao posledica uverenja da razumevanje liderskog procesa mora uključiti i konceptualizaciju različitih situacionih varijablii, od kojih se najznačajnijom smatraju karakteristike sledbenika.

Jedan od prvih modela koji je pomerio fokus proučavanja liderskog procesa sa lidera na sledbenike, jeste model situacionog liderstva P. Hersey-a i K. Blanchard-a (1989), koji zagovaraju ideju da se odnos 
između dve bazične dimenzije ponašanja lidera (orijentisanost na zadatke i orijentisanost na ljude) formira u zavisnosti od karakteristika sledbenika. Hersey-Blanchard-ov model liderstva bazira se na uspostavljanju relacija između liderskih stilova usmeravanja i socijalne podrške članovima grupe, s jedne strane, kao i spremnosti, odnosno, zrelosti sledbenika koju oni ispoljavaju u obavljanju specifičnih zadataka, s druge strane. Upravo ova situaciona varijabla predstavljala je novu dimenziju liderskog procesa $\mathrm{u}$ odnosu na prethodne, a njenim isticanjem $\mathrm{u}$ prvi plan akcentira se uloga sledbenika kao značajnog faktora svakog procesa liderstva. Na ovaj način, središte pažnje pomereno je sa lidera na sledbenike, čija se uloga smatra ključnom, kako zbog toga što su oni ti koji mogu da prihvate ili odbace lidera, tako i zbog činjenice da njihove karakteristike determinišu liderski stil koji će biti primenjen u konkretnoj situaciji.

Za razliku od shvatanja zrelosti $u$ apsolutnom smislu, pojam zrelosti u situacionoj teoriji liderstva, $\mathrm{u}$ organizacionom smislu, tumači se kao „sposobnost i spremnost ljudi da usmeravaju svoje ponašanje $u$ pravcu ostvarenja određenog zadatka" (Hersey \& Blanchard, 1989). Zrelost se, dakle, u ovom slučaju, posmatra kao relativna kategorija $\mathrm{u}$ odnosu na konkretni zadatak i okolnosti, što implicira da pojedinac ili grupa mogu biti spremni i sposobni za obavljanje jednog, ali ne i za obavljanje drugog posla. Koncept zrelosti u Hersey-Blanchard-ovom modelu sastoji se iz dve ključne komponente (Hersey \& Blanchard, 1989):

- poslovna zrelost (sposobnost), ogleda se u znanju, iskustvu i obučenosti da se obavi određeni zadatak bez direktnog usmeravanja i nadgledanja;

- psihološka zrelost (spremnost), podrazumeva motivisanost i volju da se nešto preduzme, što uključuje posvećenost, samopouzdanje i spremnost da se preuzme odgovornost.

Kombinacija navedenih komponenata definiše stepen zrelosti, koja se izražava kroz nivoe, pri čemu različiti nivoi zrelosti u matrici „orijentisanost na zadatak/ orijentisanost na interakcije", impliciraju primenu različitih liderskih stilova (Hersey \& Blanchard, 1989). Suština ovog modela liderstva ogleda se u činjenici da nivo zrelosti sledbenika determiniše optimalni vid ponašanja lidera, $u$ smislu da sa porastom zrelosti i spremnosti sledbenika, raste orijentisanost lidera na interakcije i podršku, dok sa opadanjem zrelosti raste primena direktivnih stilova vođstva.

Teorija put-cilj, koja je u značajnoj meri promovisala ulogu sledbenika u liderskom procesu, orijentisana je na motivaciju sledbenika u odnosu lider-sledbenik, radi povećanja i zadovoljstva pa, samim tim, i većeg angažovanja sledbenika u procesu realizacije organizacionih ciljeva (House, 1971). Motivaciona funkcija lidera $u$ ovom procesu sastoji se u povećanju nagrada sledbenicima za ostvarene rezultate i stvaranju puta za lakše dobijanje nagrada, kroz objašnjavanje, uklanjanje prepreka i povećanje mogućnosti za ostvarenje zadovoljstva obavljanjem posla. Osnova teorije put-cilj nalazi se u shvatanju da će lideri biti efektivni $u$ stepenu $u$ kom upotpunjuju okruženje $\mathrm{u}$ kom njihovi sledbenici rade, putem neophodnih pojašnjenja delegiranih zadataka, kako bi osigurali da sledbenici mogu da ostvare organizacione ciljeve, da osete lično zadovoljstvo i da dobiju adekvatne nagrade za ostvarene ciljeve (House, 1996; Kamisah \& Wafa, 2014). Lideri će uspešno motivisati sledbenike ako učine poslovne rezultate poželjnim i ako pomognu sledbenicima da razumeju ponašanja i strategije koje vode ostvarenju željenih rezultata i nagrada (House \& Mitchell, 2000; Knight, Shteynberg \& Hanges, 2004). Način na koji će sledbenici doživljavati nagradu zavisi u velikoj meri od stila liderstva - ukoliko lideri pružaju pomoć i podršku, obezbeđujući jasan pravac akcije i put ostvarenja cilja, onda i samo ponašanje lidera može biti doživljeno kao specifična nagrada.

Teorija se zasniva na dve generalne pretpostavke. Prvo, ponašanje lidera prihvatljivo je i zadovoljavajuće za sledbenike jedino u meri u kojoj je percipirano kao izvor trenutne ili instrument za ostvarenje buduće satisfakcije. Drugo, ponašanje lidera delovaće motivišuće $u$ meri $u$ kojoj se zadovoljenje potreba sledbenika dovede $u$ funkciju sa efektivnim performansama, pri čemu lider mora da doprinese stvaranju okruženja koje će stimulisati veće performanse, obezbeđujući podršku i pomoć. S tim u vezi, R. J. House (1996) je smatrao da se osnovne funkcije lidera mogu ostvariti primenom jednog od četiri stila liderskog ponašanja: 
- direktivni stil - lider naglašava formalne aktivnosti, obezbeđuje jasnu direktivu, planove, pravila, procedure i standarde;

- podržavajući stil - lider ukazuje pažnju članovima grupe i kreira klimu emotivne podrške, ponaša se prijateljski i tretira podređene kao sebi ravne;

- participativni stil - lider se konsultuje sa sledbenicima i razmatra njihove ideje prilikom donošenja odluka;

- stil orijentisanja postignućima - lider ohrabruje zaposlene da preuzmu komplikovane zadatke, postavlja izazovne ciljeve, nagrađuje izuzetne rezultate i podstiče samopouzdanje zaposlenih.

Koji će liderski stil dominirati $\mathrm{u}$ određenim okolnostima, zavisi od niza kontingentnih varijabli, koje su u okviru modela put-cilj svrstane u dve grupe:

- personalne karakteristike sledbenika, kao što su lokus kontrole, sposobnost obavljanja zadatka, potreba za postignućima, iskustvo i potreba da se zadatak jasno definiše;

- karakteristike okruženja, kao što su stepen strukture zadataka, sistem formalnog autoriteta i karakteristike radne grupe.

Pomenute karakteristike predstavljaju situacione moderatore koji determinišu potencijal za povećanje motivacije sledbenika, kao i liderski stil koji će najbolje odgovarati određenim uslovima. Procena situacionih faktora može omogućiti predviđanje efekata uticaja pojedinih liderskih stilova na stavove i performanse zaposlenih, pa, samim tim, i izbor adekvatnog stila u konkretnim okolnostima. Tako, na primer, kada je zadatak stresan, opasan ili, pak, dosadan i destimulišući, podržavajući stil može da doprinese povećanju samopouzdanja, smanjenju anksioznosti i minimiziranju neprijatnih aspekata posla, što će dovesti do povećanja satisfakcije i radnih napora sledbenika. Ukoliko je zadatak nestrukturiran i kompleksan, podređeni neiskusni, a postoji slaba formalizacija pravila i procedura, tada će direktivno liderstvo biti najprikladniji stil koji će generisati veću satisfakciju i veće napore. Direktivno ponašanje redukuje nejasnoće koje postoje kada uloge i zadaci nisu jasno definisani, pa je neophodno razgraničiti odgovornosti, utvrditi pravila i obezbediti precizne smernice delovanja. Stil ponašanja orijentisan na dostignuća adekvatan je $u$ slučajevima nerepetitivnih zadataka koji predstavljaju svojevrsni izazov za zaposlene, te im je neophodno povećati samopouzdanje i podstaći očekivanje da će uspešno i kompetentno ostvariti postavljeni cilj, dok je participativni stil primeren situacijama u kojima je neophodno da sledbenici budu uključeni u donošenje odluka, kao i u slučajevima kada podređeni imaju snažnu potrebu za samostalnošću i nezavisnošću.

Najznačajnije implikacije teorije zrelosti sledbenika i teorije put-cilj, odnose se na potvrdu stava da lideri mogu posedovati i koristiti više od jednog stila liderstva, i da je izbor liderskog stila direktno determinisan karakteristikama i potrebama sledbenika.

\section{INDIVIDUALIZIRANI PRISTUP LIDERSTVU: TEORIJA RAZMENE LIDER- SLEDBENIK}

Rane teorije liderstva posmatrale su liderstvo kao aktivnost koju lideri preduzimaju prema svim svojim sledbenicima, članovima iste grupe, uniformno, koristeći tzv. prosečan liderski stil (Northouse, 2008). Novija istraživanja dovode u pitanje ovu pretpostavku, ukazujući na činjenicu da lider uspostavlja specifičan odnos sa svakim svojim sledbenikom pojedinačno, i da se taj odnos ostvaruje putem razmene koja se vrši kroz razvijene interpersonalne odnose, što znači da se lider najčešće ne ponaša isto prema svim svojim sledbenicima, već sa nekima uspostavlja odnose razmene višeg, a sa nekima nižeg kvaliteta.

Za razliku od prethodnih teorija i pristupa liderstvu, koje ovaj proces posmatraju kroz uspostavljanje odnosa lidera i čitave grupe, dvosmerni pristup fokusira se na relaciju lider - pojedinačni član grupe, ukazujući da liderstvo nije proces koji se uniformno manifestuje prema svim članovima organizacije, već da lider formira specifičan odnos sa svakim članom grupe pojedinačno, što implicira da se ne može govoriti o ponašanju generalno orijentisanom na zadatak ili na međuljudske odnose, već se mora razmatrati svaka 
interakcija lider-sledbenik pojedinačno (Graen \& UhlBien, 1995; Yukl, 1998; Green, 2008; Daft, 2011).

Dvosmerni pristup liderstvu, $\mathrm{u}$ literaturi poznat kao Vertical Dyad Linkage - VDL model, bazira se na individualnoj razmeni lider-član, pa se zbog toga naziva i pristup razmene Leader Member Exchange LMX. Bazična premisa ovog pristupa zasniva se na ideji recipročnog uticaja lidera na sledbenike, koji može poprimiti dve različite forme. Smatra se, naime, da većina lidera uspostavlja specifične odnose razmene sa malim brojem članova jedne grupe, sa kojima razvija bliske odnose i koji dobijaju ulogu njegovih pomoćnika i savetnika, dok drugi deo članova grupe biva relativno zanemaren, ili se sa njima uspostavljaju nešto lošiji odnosi, zbog čega se oni često smatraju oponentima lidera (Northouse, 2008). U razmeni sa ovim članovima grupe ispoljava se relativno nizak nivo međusobnog uticaja, koji se zasniva, uglavnom, na legitimnim izvorima moći i autoriteta, a realizuje se $\mathrm{u}$ okviru formalno definisanih pravila i procedura. Kompleksniji odnosi razmene, koji se uspostavljaju sa preferiranim članovima grupe, podrazumevaju da ovi članovi dobijaju više pažnje, priznanja i mogućnosti za napredovanje, ali za uzvrat se od njih očekuje i veće angažovanje, posvećenost ciljevima i zadatku, kao i veća lojalnost lideru.

Članovi unutrašnje grupe, sa kojima se uspostavljaju bliski odnosi u razmeni, biraju se na osnovu veština sledbenika, njihove motivacije za preuzimanje odgovornosti, i stepena u kom lideri smatraju da sledbenicima mogu verovati. Sledbenici koji pokazuju viši stepen efikasnosti i imaju slične karakteristike ličnosti kao lider, pre će postati članovi unutrašnje grupe, zbog efekta tzv. egocentrične atribucije (Schyns, Kroon \& Moors, 2008). Ovi sledbenici doprinose obavljanju zadatka više nego što se od njih očekuje prema formalnim zahtevima posla, i preuzimaju odgovornost za obavljanje poslova koji su najkritičniji za uspeh organizacije. Oni imaju poseban tretman od strane lidera, u smislu da im se obezbeđuje veća količina informacija, veća posvećenost, pažnja, podrška u razvoju karijere, razumevanje, uživaju veće poverenje i brigu lidera (Jiang, Law \& Sun, 2014). Sledbenici unutrašnje grupe imaju više mogućnosti da otvoreno govore, da razmenjuju informacije i ideje sa svojim nadređenim, da koriste više kanala komunikacije od sledbenika iz spoljašnje grupe (Sue-Chan, Chen \& Lam, 2011). Ovi sledbenici su zadovoljniji poslom, postižu bolje performanse, veću kreativnost i inovativnost, i posvećeniji su organizaciji od sledbenika iz spoljašnje grupe (Van Breukelen, Schyns \& Le Blanc, 2006; Lee, 2008; Moss, Sanchez, Brumbaugh \& Borkowski 2009; O’Donnell, Yukl \& Taber, 2012; Abu Elanain, 2014). Sledbenici iz unutrašnje grupe ređe napuštaju posao i imaju više ocene radnog učinka. Lideri i sledbenici sa kojima imaju bliske odnose, pomažu jedni drugima u karijeri, ali i ličnom životu, često sarađuju na poslu, ali i neformalno van posla. Visokokvalitetni odnosi razmene lidera sa članovima unutrašnje gupe se mogu smatrati vrstom socijalnog kapitala, koji ima pozitivan uticaj na ukupne organizacione performanse (Moss et al, 2009; Jiang et al, 2014).

Članovi spoljašnje grupe obavljaju, uglavnom, rutinske zadatke (Stewart \& Johnson, 2009), i imaju formalne odnose sa nadređenima, koji se karakterišu niskim poverenjem, nedostatkom pažnje, podrške i manjim mogućnostima za nagrade (Moss et al, 2009). Sledbenici iz spoljašnje grupe obavljaju isključivo zadake za koji su angažovani i koji su u skladu sa formalnim opisom njihovog posla (Abu Elanin, 2014), imaju manje kontakata sa liderom, manje resursa i ograničen pristup informacijama. Lider im pruža podršku i pomoć, ali isključivo u meri onoga što je njegova dužnost i profesionalna obaveza. Ovi sledbenici imaju manje šanse za napredovanje, često se osećaju izolovano i zanemareno, teže razvijaju osećaj privrženosti i posvećenosti organizaciji, doživljavajući svoju poziciju izrazito nepravednom (Loi, Mao \& Ngo, 2009).

Novija istraživanja $\mathrm{u}$ ovoj oblasti fokusirana su na nastojanja da se razvije model razmene, koji bi omogućio uspostavljanje efektivnih relacija lidera sa svim članovima grupe, bez obzira na činjenicu da su te relacije i dalje bazirane na individualiziranim odnosima. Akcenat je na naporima da se svim zaposlenima obezbedi mogućnost učestvovanja $\mathrm{u}$ kvalitetnom procesu razmene lider-član, čime se generišu koristi za sve učesnike tog procesa: lidere, sledbenike i organizaciju u celini (Daft, 2011). U tom kontekstu, lider sagledava svakog sledbenika nezavisno, i tretira ga kao individuu, razvijajući na taj način poseban vid tzv. „individualiziranog 
liderstva“, koje podrazumeva aktivni razvoj pozitivnih odnosa sa svim članovima grupe, iako taj odnos poprima drugačiju formu za svakog pojedinca (Daft, 2011). To znači da lider u svojim nastojanjima može manifestovati različite vidove ponašanja istovremeno, s tim da će prema nekim pojedincima ispoljavati više pažnje i obzira, u skladu sa orijentacijom na interakcije, a prema drugima više direktivnog ponašanja, $u$ skladu sa orijentacijom na zadatak, sve u zavisnosti od njihovih individualnih karakteristika.

Sistemska perspektiva ove teorije sugeriše mogućnost ekspanzije vertikalne dvosmerne veze na druge pravce, što implicira uspostavljanje odnosa razmene lider-sledbenik izvan tradicionalnih granica funkcija i diviziona, pa čak i izvan organizacionih okvira. Ovo podrazumeva nastojanja da se liderski odnosi prošire tako da obuhvate sve relevantne stakeholder-e, omogućujući lideru da svoje sposobnosti selektivno koristi, kreirajući pozitivne odnose sa što većim brojem ljudi, i šireći na taj način polje svog uticaja.

\section{KONCEPTI USLUŽNOG LIDERSTVA I PODELJENOG VOĐSTVA}

Uslužno liderstvo predstavlja perspektivu procesa liderstva u potpunosti usmerenog na sledbenike, $u$ kojoj se uloga lidera ne doživlja kao direktivna ni u jednom segmentu, već isključivo kao podržavajuća, a glavna težnja lidera nije da dominira, već da pomaže svojim sledbenicima (Greenleaf, 1998). Prema ovom konceptu, pozicija lidera ne obezbeđuje privilegije, već obavezuje, i mora se zaslužiti pružanjem podrške i pomoći sledbenicima. "Jedini autoritet koji treba prihvatiti je onaj koji se dobija u zamenu za pružanje pomoći. Jedini lideri koje treba slediti su oni koji su se dokazali kao pomoćnici, spremni da najpre služe, a tek nakon toga da vode“ (Greenleaf, 1998, 25).

Za razliku od tradicionalnog liderstva koje efikasnost liderskog procesa meri klasičnim output-ima, uslužno liderstvo posmatra efikasnost u kontekstu realizovanja potreba članova organizacije, kao što su zadovoljstvo, napredovanje, samoostvarenje, autonomija, sigurnost i sl. Tradicionalni lideri preferiraju instrukcije i direktivu, dok uslužni lideri akcenat stavljaju na pomoć, olakšavanje i usmeravanje, koje će sledbenicima omogućiti da potpunije sagledaju svoje okruženje, i razumeju zahteve koji se pred njih postavljaju. Dve suštinske premise određuju prirodu uslužnog liderstva: želja lidera da služi drugima, potreba da se služi nečemu što predstavlja viši cilj ili svrhu, i prevazilazi okvire sopstvenih interesa; i spremnost lidera da podeli moć sa svojim sledbenicima (Greenleaf, 1998).

Uslužni lideri nastoje da kreiraju osećaj zajedništva i pripadnosti organizaciji, ohrabrujući sledbenike da se angažuju izvan okvira svojih tekućih radnih uloga, podstičući njihov lični i profesionalni razvoj i kontinuirano učenje (Kreitner \& Kinicki, 2012). Odlikuje ih sposobnost aktivnog slušanja, razumevanje potreba i želja saradnika, izražena empatija i poverenje u dobre namere svojih sledbenika, čak i onda kada su ishodi loši. U kontekstu napred pomenutog pristupa razmene lider-sledbenik, uslužno liderstvo podrazumeva najviši stepen individualizacije liderstva, u kome svi sledbenici zauzimaju poziciju internih članova grupe $\mathrm{u}$ visokokvalitetnom odnosu razmene. Ono zahteva potpuno prilagođavanje liderskog stila konkretnim potrebama, sposobnostima i ograničenjima svakog sledbenika pojedinačno, uz prepuštanje liderske uloge sledbenicima kad god je to moguć (Kreitner \& Kinicki, 2012). Na taj način, gubi se jasna granica između lidera i sledbenika, mada u slučaju uslužnog liderstva grupa nema problem da identifikuje lidera, čak i ukoliko se nalazi izvan formalne pozicije autoriteta.

Esencijalni preduslov jačanja uloge sledbenika $\mathrm{u}$ liderskom procesu u organizaciji bazira se na podeli moći, s obzirom na to da moć predstavlja jednu od ključnih dimenzija liderstva neophodnu za vršenje uticaja (Keley, 1988). Tradicionalno lidersko razmišljanje promoviše ideju da je moć fiksirana veličina, te da ukoliko jedna osoba ima više moći, druge je nužno moraju imati manje. Prirodno, ljudi sa ovakvim shvatanjem nisu raspoloženi da dele moć, verujući da što manje moći poseduju podređeni, to je njima lakše upravljati. Praksa je, međutim, pokazala da nedostatak moći kod podređenih dovodi do drastičnog slabljenja motivacije i loših rezultata, a slično važi i za lidere - oni čija se moć bazira samo na legitimnoj poziciji uz nedostatak drugih vidova moći, skloni su primeni autokratskog stila vođstva i stvaranju 
sistema $\mathrm{u}$ kome političke sposobnosti dominiraju nad liderskim, a zaštita sopstvenih interesa postaje primarna, zbog čega sledbenici postaju demotivisani, frustrirani i nekooperativni (Gardner, Avolio, Luthans, May \& Walumbwa, 2005).

Mnogobrojna istraživanja pokazala su da što sledbenici više veruju da su uticajni, moćni i da mogu da kontrolišu određene segmente poslovanja, to je veća njihova lična satisfakcija, koja se pozitivno odražava na ukupnu efikasnost organizacije (Greenleaf, 1998; Daft, 2011; Jiang, et al, 2014). Između podele moći i uspeha najčešće postoji visok stepen korelacije - oni delovi organizacije kod kojih postoji veća podela moći između lidera i sledbenika, pokazuju veću efikasnost i veći stepen moći u celini (Bucic, Robinson \& Ramburuth, 2010). Za ove organizacione podsisteme karakteristično je da lideri ne doživljavaju moć kao nedeljivo dobro, već shvataju da je uspeh cele grupe veći ukoliko više njenih članova ima razvijen osećaj moći i sposobnost vršenja uticaja. Koncept podele moći podrazumeva određeni reciprocitet uticaja, što znači da su i lider i sledbenik spremni da uzajamno utiču jedni na druge (Pierce \& Newstorm, 2015). Radeći na jačanju drugih, lider sebe stavlja $u$ ravnopravan položaj sa sledbenicima, motivišući ih na taj način da podržavaju njegove ideje, umesto da ih sabotiraju. To dovodi do povratnih sinergijskih efekata, pa i lider dobija više moći nego što je prethodno imao.

Jednu od ključnih pretpostavki osamostaljivanja i podeljenog vođstva, predstavlja omogućavanje sledbenicima da donose odluke bez stalne provere lidera, što im daje osećaj lične autonomije i samokontrole, i utiče na povećanje moći i motivacije (Pierce \& Newstorm, 2015). U tom smislu, neophodno je da lider bude konzistentan u svojim namerama da podstiče uključivanje sledbenika $u$ rešavanje problema od najranijih faza, da bude iskreno posvećen zadatku i deluje sopstvenim primerom. Neophodno je, dakle, da sledbenici imaju poverenje u lidera, ali je potrebno i da lider veruje u sposobnosti i kapacitete svojih sledbenika, pružajući podršku i obezbeđujući mogućnost informisanja, obrazovanja i razvoja novih znanja i veština. Sledbenici ovakvih lidera osećaju snažnu pripadnost grupi i posvećenost poslu koji obavljaju, odgovorni su za svoja zaduženja i spremni za kontinuirano usvršavanje (Pierce \& Newstorm,
2014). Podeljeno vođstvo podrazumeva neprekidni proces prepoznavanja liderskih potencijala među zaposlenima i njihovo podsticanje da te potencijale razvijaju, kako bi se povremeno i sami našli u ulozi lidera (Stojanović Aleksić i Domanović, 2012; Eric Nielsen, 2015).

Implementacija koncepta podeljenog vođstva podrazumeva određene karakteristike sledbenika, čija se uloga menja od pasivne ka aktivnoj, i koji se mogu opisati kao efektivni sledbenici. Efektivne sledbenike karakteriše osećaj lične odgovornosti za ostvarenje definisanih ciljeva i zajedničke organizacione misije, preuzimanje inicijative za aktivnosti kojima se obezbeđuje unapređenje sopstvenih potencijala, uz nastojanje da se prepoznaju potrebe organizacije i radi na njihovom zadovoljenju, zajedno sa liderom (Kelly, 2012). Osim toga, odlikuje ih sposobnost da jasno $i$ slobodno izraze svoje mišljenje i suprotstave se lideru, ukoliko se time sprečavaju aktivnosti kojima bi se ugrozio integritet ili ciljevi organizacije (Kelly, 2012; Pierce \& Newstorm, 2015).

Efektivnost sledbenikauslovljenaje, dakle, sposobnošću da se integrišu dve opozitne sledbeničke uloge - jedna vezana za implementaciju odluka donetih od strane lidera, i druga koja se odnosi na potrebu preispitivanja liderskih odluka i aktivnosti i predlaganje kreativnih rešenja. Ovo je posebno značajno u procesu suočavanja organizacije sa transformacionim promenama, kada spremnost sledbenika da se suoče sa neizvesnošću i rizikom, postaje kritični faktor uspeha njihovog iniciranja i vođenja.

Transformacione promene zahtevaju i primenu transformacionog liderstva, koncepta veoma bliskog konceptu podeljenog vođstva, a različitog u odnosu na transakciono vođstvo. Transkaciono liderstvo zasniva se na principima razmene (transakcije) na relaciji lidersledbenik, pri čemu sledbenik ulaže svoje potencijale i angažuje se $\mathrm{u}$ ostvarivanju određenog cilja, $\mathrm{u}$ zamenu za različite vidove nagrada koje dobija od lidera (Tichy \& Devanna, 1996). Ovakav odnos, koji veoma podseća na klasičan odnos nadređeni-podređeni, može biti uspešan u realizaciji tekućih ciljeva organizacije, ali vrlo retko dovodi do suštinskih organizacionih promena (Georgiades \& Macdonell, 2008). S druge strane, transformaciono liderstvo podrazumeva 
inspiraciju i mobilisanje energije sledbenika radi promene postojećeg stanja $\mathrm{u}$ organizaciji, $\mathrm{uz}$ istovremenu transformaciju samih sledbenika $u$ pravcu jačanja njihove efektivne uloge $u$ liderskom procesu.

Transformaciono liderstvo se bazira na tri suštinske komponente: vizija, energija, osposobljavanje (Tichy \& Devanna, 1996). Ono, dakle, nužno podrazumeva kreiranje ubedljive vizije onog što se želi ostvariti procesom promena, uz razvoj strategija i modeliranje ponašanja koje će dovesti do njene realizacije. Uz to, transformaciono liderstvo zahteva angažovanje značajne energije, kako lidera tako i sledbenika, na taj način što će se od njih zahtevati veći napori i zalaganja, uz demonstriranje sopstvene inicijative $i$ vere $u$ zajednički uspeh, kao i promovisanje i nagrađivanje svih značajnijih pomaka u pravcu željenih promena. Treća komponenta transformacionog liderstva vezana je za osposobljavanje sledbenika i uključuje ličnu podršku i pomoć, ispoljavanje razumevanja, spremnosti da se podele osećanja sa članovima organizacije, kao i demonstriranje poverenja u njihovu sposobnost da na adekvatan način odgovore izazovima promena, što su, takođe, i odlike koncepta podeljenog vođstva. U izvesnom smislu, može se reći da transformaciono liderstvo zahteva i transformacione sledbenike

\section{ZAKLJUČAK}

Proces liderstva je uslovljen dejstvom različitih faktora, koji obuhvataju osobine lidera, strukturu moći, zahteve specifične situacije, karakteristike sledbenika, kao i povratne informacije o uticaju različitih stilova ponašanja lidera na performanse sledbenika (Pierce \& Newstorm, 2015). Zbog toga je liderstvo neophodno posmatrati kao interaktivni proces determinisan mnoštvom varijabli, pa stoga, u model liderstva treba integrisati čitav kompleks relevantnih faktora, sa posebnim akcentom na karakteristike sledbenika. Bitna odlika svakog liderskog procesa jeste da se on uvek odvija u okviru određene grupe i u kontekstu specifične situacije, pa u tom svetlu treba posmatrati i različite aspekte sagledavanja uticaja lidera na sledbenike, i obrnuto.
Savremene organizacione okolnosti naglašavaju potrebu da lideri budu u službi svojih sledbenika, otvoreni za sve vrste ideja i sugestija, spremni da podrže, pomognu i podstaknu na veće napore i zalaganja, zbog čega se, kao jedan od najznačajnijih kriterijuma uspešnosti lidera, posmatra stepen $u$ kome su i njegovi sledbenici uspešni, zadovoljni i sposobni da sami sebe vode. Efektivni lideri uviđaju da postoje limiti za ono što mogu sami da urade, i da je jedan od načina za njihovo prevazilaženje da svoje sledbenike učine sposobnijim i motivisanijim, koristeći sopstvenu moć u službi razvoja ostalih članova organizacije. Čak i lideri autokratskog tipa ne bi bili u stanju da uspešno funkcionišu, ukoliko bar nekom od svojih sledbenika ne bi dali osećaj moći, inspirišući ih tako za ostvarivanje zadatih ciljeva (Kouzes \& Posner, 2007).

Kontekst kontinuiranih organizacionih promena, karakterističnih za savremeno okruženje, zahteva punu i aktivnu posvećenost svih aktera liderskog procesa, što implicira nužnost napuštanja negativne koncepcije uloge sledbenika, kao pasivnih i zavisnih učesnika $u$ liderskom procesu, i njene zamene pozitivnom, koja uključuje sledbenike koji su odgovorni, proaktivni i spremni na promene, rizik i neprestano učenje (Chaleff, 2005).

Formiranje efektivnih relacija na liniji lider-sledbenik podrazumeva objektivno sagledavanje pozicije lidera, koje isključuje idealizaciju njegove ličnosti i uloge, što nije lako ostvariti jer je većina lidera, u manjoj ili većoj meri, idealizovana od strane svojih sledbenika (Ansari, Mui Hung \& Afaqi, 2007). S druge strane, neophodno je da sledbenici sami sebe procene na realan način, registrujući svoje prednosti i ograničenja, analizirajući sve što je značajno za ostvarivanje međusobnog poverenja i podrške u odnosu sa liderom. Kreativnost, inicijativa, sklonost promenama, spremnost da se preuzme odgovornost i doprinese razvoju organizacije, poželjne su osobine sledbenika, koje čine važan deo liderskog procesa, i neophodne su za realizaciju koncepta podeljenog vođstva. U savremenim organizacionim okolnostima, značajna karakteristika efektivnog sledbenika vezana je za spremnost i sposobnost da se napusti relacija lider-sledbenik, ukoliko sledbenik nije zadovoljan svojim statusom $\mathrm{u}$ liderskom procesu, ili nije $\mathrm{u}$ stanju da odgovori zahtevima lidera. To znači da nijedan liderski proces 
ne bi trebalo da se posmatara kao trajna kategorija, već isključivo kao privremeni odnos moći, uvek povezan sa specifičnim situacionima okolnostima, što implicira rotacionu prirodu liderske i sledbeničke uloge.

Naučni doprinos rada u teorijskom smislu, ogleda se $\mathrm{u}$ isticanju značaja istraživanja fenomena liderstva sa aspekta sledbenika, kao i u osvetljavanju uloge sledbenika u procesu organizacionog liderstva, kao aktivnih i ravnopravnih učesnika ovog procesa. $U$ tom kontekstu, potvrđena je naučno validna hipoteza da je kvalitet liderskog procesa, pored karakteristika lidera, uslovljen i karakteristikama sledbenika, odnosno, da postoji međuzavisnost efektivnosti liderskog procesa i aktivne uloge sledbenika u tom procesu.

Teorijski pristup sintetizovan $\mathrm{u}$ radu predstavlja osnovu za moguća buduća teorijska i empirijska istraživanja, a njegov praktičan dopinos ogleda se $\mathrm{u}$ davanju smernica liderima $\mathrm{u}$ organizaciji za aktivnije uključivanje sledbenika $u$ proces donšenja odluka, podelu moći i prilagođavanje liderskog stila specifičnostima samih sledbenika, kao i zahtevima situacionih okolnosti.

Najveće ograničenje rada ogleda se u nedostatku empirijskog istraživanja, kojim bi se istražile karakteristike sledbenika u kontekstu kulturoloških i organizacionih specifičnosti domaćih preduzeća, i ispitale konkretne relacije $\mathrm{u}$ odnosu razmene lidersledbenik $\mathrm{u}$ procesu organizacionog liderstva $\mathrm{u}$ Republici Srbiji. Buduća istraživanja biće usmerena na otklanjanje ovih nedostataka, posebno na analiziranje uticaja nacionalne $\mathrm{i}$ organizacione kulture na uspostavljanje relacija lider-sledbenik, kao i na razmatranje kulturoloških ograničenja u primeni koncepata uslužnog liderstva i podeljenog vođstva.

Evidentno je da proces liderstva $u$ savremenim organizacijama ne može da se odvija nezavisno od aktivnog učešća sledbenika, tako da će u godinama koje dolaze uloga sledbenika sve više dobijati na značaju, kako u teoriji, tako i u organizacionoj praksi. U tom kontekstu, treba očekivati sve veći broj empirijski istraživanja u okviru ovog problemskog područja, što će biti i jedan od pravaca budućih istraživanja autora ovog rada.

\section{REFERENCE}

Abu Elanain, H. M. (2014). Leader-member exchange and intent to turnover: Testing a mediated-effects model in a high turnover work environment. Management Research Review, 37(2), 110-129. 10.1108/MRR-09-2012-0197

Ansari,M.A.,MuiHung,D.K.,\&Afaqi,R.(2007).Leader-member exchange and attitudinal outcomes: role of procedural justice climate. Leadership \& Organization Development Journal, 28(8), 690-709. doi:10.1108/01437730710835443

Bucic, T., Robinson, L., \& Ramburuth, P. (2010). Effects of leadership style on team learning. Journal of Workplace Learning, 22(4), 228-248. doi: 10.1108/13665621011040680

Bowditch, J. L., Buono, A. F., \& Stewart, M. M. (2008). A Primer on Organizational Behavior. $7^{\text {th }}$ edition. New York, NY: Wiley.

Chaleff, I. (2005). The Courageous Fellower: Standing up to and for our Leaders. San Francisco, USA: Berrett Koehler Publishers.

Conger, J., \& Kohungo, R. (1990). A behavioral attribute measure of charismatic leadership in organizations. Academy of Management Meetings, 637-647.

Daft, R. L. (2011). Leadership: Theory and Practice. Forth North, USA: The Dryden Press.

Eric Nielsen, J. (2015). Corporate entrepreneurship, organizational learning and knowledge implementation. Economic Horizons, 17(3), 2013-217. doi: 10.5937/ ekonhor1503203E

Gardner, W. L., Avolio, B. J., Luthans, F., May, D. r., \&Walumbwa, F. (2005). Can you see the real me? A self-based model of authentic leader and follower development. The Leadership Quarterly, 16(3), 343-372. doi:10.1016/j.leaqa.2005.03.003

Georgiades, N., \& Macdonell, R. (2008). Leadership for Competitive Advantage. Chichester, UK: John Wiley\&Sons.

Graen, G. B., \& Uhl-Bien, M. (1995). Relationship-based approach to leadership: Development of leader-member exchange $(\operatorname{lmx})$ theory of leadership over 25 years: Applying a multi-level multi-domain perspective. Leadership Quarterly, 6(2), 219-247. doi:10106/1048-9843(95)90036-5

Green, C. (2008). Leader member exchange and the use of moderating conflict management styles: Impact on relationship quality. International Journal of Conflict Management, 19(2), 92-111. doi:10.1108/1044406810856058

Greenleaf, R. (1998). Servant Leadership. In L. C. Spears (Ed.), Insights on Leadership. New York, NY: John Wiley\&Sons.

Hersey, P., \& Blanchard, K. H. (1989). Management of Organizational Behavior: Utilizing Human Resources. New 
York, NY: Prentice Hall.

House, R. J. (1971). A path goal theory of leader effectiveness. Administrative Science Quarterly, 16(3), 321-339. doi:10.2307/2391905

House, R. J. (1996). Path-goal theory of leadership: Lessons legacy and a reformulated theory. The Leadership Quarterly, 7(3), 323-352. doi:10.1016/S1048-9843(96)90024-7

House, R. J., \& Mitchell, T. R. (2000). Path-Goal Theory of Leadership. New York, NY: McGraw Hill.

Isam, T., Rehman, S., \& Ahmed, I. (2013). Investigating the mediating role of organizational politics between leadership style and followers' behavioral outcomes. Business Strategy Series, 14(2/3), 80-96. doi.10.1108/17515631311325123

Jiang, J. Y., Law, K. S., \& Sun J. J. M. (2014). Leader-member relationship and burnout: The moderating role of leader integrity. Management and Organization Review, 10(2), 223-247. doi: 10.1111/more.12022

Kamisah, D. A. B., \& Wafa, S. A. (2014). The leadership style preference among sabah ethnicities. International Journal of Human Resource Studies, 4(1), 259-265. doi:10,5296/ ijhrsv4i1.5708

Kelley, R., (1988). In price of followers. Harvard Business Review, Novembar, 142-158. Retrieved May 20, 2016, from https://hbr. org/1988/11/in-praise-of-followers

Kelly, R. (2012). The Power of Followership. New York, NY: Doubleday.

Knight, A. P., Shteynberg, G., \& Hanges, P. J. (2004). Path-goal analysis. In J. M. Burns, G. R. Goethals, \& G. J. Sorenson (Eds.), Encyclopedia ofleadership (pp.1164-1169). Massachusetts, USA: Sage Publications.

Kouzes, J., \& Posner, B. (2007). Leadership Chalenge. San Francisco, USA: Jossey Bass Publishers.

Kreitner, R., \& Kinicki, A. (2012). Organizational Behavior. New York, NY: MC Graw Hill.

Lee, J. (2008). Effects of leadership and leader-member exchange on innovativeness. Journal of Managerial Psychology, 23(6), 670-687. doi:10.1108/02683940810894747

Loi, R., Mao, Y., \& Ngo, H. (2009). Linking leader-member exchange and employee work outcomes: The mediating role of organizational social and economic exchange. Management and Organization Review, 5(3), 401-422. doi: 10.1111/j.1740-8784.2009.00149.x

Meindl, J. R.(1990). On Leadership: An Alternative to Conventional Wisdom. In B. M. Staw, \& L. L. Cummings
(Eds.), Research in Organizational Behavior (pp. 159-189). Vol. 12.

Moss, S. E., Sanchez, J. I., Brumbaugh, A. M., \& Borkowski, N. (2009). The mediating role of feedback avoidance behavior in the LMX - performance relationship. Group \& Organization Management, 34(6), 645-664. doi: 10.1177/1059601109350986

Northouse, P. G. (2008). Leadership: Theory and Practice. Massachusetts, USA: Sage Publications Inc.

O’Donnell, M., Yukl, G., \& Taber, T. (2012). Leader behavior and LMX: a constructive replication. Journal of Managerial Psychology, 27(2), 143-154. doi: 10.1108/02683941211199545

Pierce, J., \& Newstrom, J. (2014). Leaders and the Leadership Process. New York, NY: IRWIN

Pierce, J., \& Newstorm, J. (2015). The Managers Bookshelf. New Yersey, NY: Prentice-Hall.

Schyns, B., Kroon, B., \& Moors, G. (2008). Follower characteristics and the perception of leader member exchange. Journal of Managerial Psychology, 23(7), 772-788. doi: $10.1108 / 02683940810896330$

Shamir, B., House, R. J., \& Arthur, M. B. (1993). The motivational effects of charismatic leadership: A self-concept based theory. Organization Science, 4(4), 577-594. doi: 10.1287/orsc.4.4.577

Stewart, M. M., \& Johnson, O. E. (2009). Leader - member exchange as a moderator of the relationship between work group diversity and team performance. Group \& Organization Management, 34(5), 507-535. doi: 10.1177/105960110833122

Stojanović Aleksić, V. i Domanović, V. (2012). Uticaj promena poslovnog ambijenta na stilove liderstva. U V. Leković (Ur.), Institucionalne promene kao determinanta privrednog razvoja Srbije (str. 295-308). Kragujevac, Republika Srbija: Ekonomski fakultet Univerziteta u Kragujevcu.

Stoner, F., \& Freman, R. (2012). Management. New York, NY: Prentice-Hall.

Sue-Chan, C., Chen, Z., \& Lam, W. (2011). LMX, coaching attributions, andemployeeperformance.Group\&Organization Management, 36(4), 466-498. doi: 10.1177/1059601111408896

Tichy, N. M., \& Devanna, M. A. (1996). The Transformational Leadership. New York, NY: Wiley.

van Breukelen, W., Schyns, B., \& Le Blanc, P. (2006). Leadermember exchange theory and research: Accomplishments and future challenges. Leadership, 2(3). 295-316. doi: $10.1177 / 1742715006066023$

Yukl, G. (1998). Leadership in Organizations. 8th Edition, New York, NY: Pearson Education. 
Primljeno 5. juna 2016, nakon revizije, prihvaćeno za publikovanje 22. avgusta 2016.

Elektronska verzija objavljena 26. avgusta 2016.

Vesna Stojanović Aleksić je vanredni profesor na Ekonomskom fakultetu Univerziteta u Kragujevcu, gde je doktorirala u oblasti Menadžmenta i poslovne ekonomije. Izvodi nastavu na nastavnim predmetima Organizacija preduzeća, Organizaciono ponašanje i Liderstvo i organizacione promene. Ključne oblasti njenog naučnog interesovanja vezane su za organizaciju, organizacione promene, liderstvo i organizaciono ponašanje.

\title{
FOLLOWERS IN THE ORGANIZATIONAL LEADERSHIP PROCESS:FROM ATTRIBUTION TO SHARED LEADERSHIP
}

\author{
Vesna Stojanovic Aleksic \\ Faculty of Economics, University of Kragujevac, Kragujevac, The Republic of Serbia
}

\begin{abstract}
Despite the fact that most of the theories and models of leadership are solely focused on the leader as the central figure of the leadership process, there is a need to draw attention to the importance of the followers' role in the organizational leadership process, which is the main subject of this paper. Newer approaches to leadership provide a framework for the study of a reciprocal influence in the leadership process, in which the behavior of the leader appears as both an independent and a dependent variable at the same time. The aim is to draw attention to the necessity of adjusting leadership styles to the characteristics of the followers and encourage the followers' active role in leadership, as the basic precondition for the effectiveness of the entire leadership process. The paper reviews the evolution of the role of the followers in organizational leadership through various approaches and models of leadership, from the attribution of potential leadership qualities through the process of attribution, through the followers' influence in the selection of the dominant leadership style, to the equal participation in the leadership process, reflected in the concepts of servant leadership and shared leadership.
\end{abstract}

Keywords: organization, leadership, followers, leadership process, organizational behavior

JEL Classification: L26, D23, O31, M13 